\title{
Quantifying the contributions of natural emissions to ozone and total fine PM concentrations in the Northern Hemisphere
}

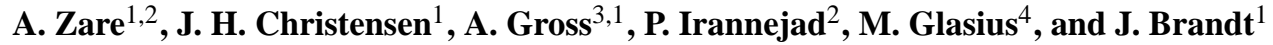 \\ ${ }^{1}$ Department of Environmental Science, Aarhus University, Aarhus, Denmark \\ ${ }^{2}$ Institute of Geophysics, University of Tehran, Tehran, Iran \\ ${ }^{3}$ AU Herning, Aarhus University, Aarhus, Denmark \\ ${ }^{4}$ Department of Chemistry and iNANO, Aarhus University, Aarhus, Denmark
}

Correspondence to: A. Zare (aza@dmu.dk)

Received: 13 May 2013 - Published in Atmos. Chem. Phys. Discuss.: 21 June 2013

Revised: 24 January 2014 - Accepted: 5 February 2014 - Published: 17 March 2014

\begin{abstract}
Accurate estimates of emissions from natural sources are needed for reliable predictions of ozone and fine particulate matter $\left(\mathrm{PM}_{2.5}\right)$ using air quality models. In this study, the large-scale atmospheric chemistry transport model, DEHM (the Danish Eulerian Hemispheric Model) is further developed, evaluated and applied to study and quantify the contributions of natural emissions of VOCs, $\mathrm{NO}_{\mathrm{x}}, \mathrm{NH}_{3}, \mathrm{SO}_{2}$, $\mathrm{CH}_{4}, \mathrm{PM}, \mathrm{CO}$ and sea salt to the concentration of ozone and formation of $\mathrm{PM}_{2.5}$ for the year 2006. Natural source categories adopted in the recent model are vegetation, lightning, soils, wild animals and oceans. In this study, the model has been further developed to include more Biogenic Volatile Organic Compounds (BVOCs) and to implement a scheme for secondary organic aerosols as well as an updated description of sea-salt emissions. Our simulations indicate that in the Northern Hemisphere the contribution from natural emissions to the average annual ozone mixing ratios over land is between 4-30 ppbV. Among the natural emissions, BVOCs are found to be the most significant contributors to ozone formation in 2006, enhancing the average ozone mixing ratio by about $11 \%$ over the land areas of the Northern Hemisphere. The relative contribution of all the natural emissions to ozone is found to be highest in the northern part of South America by about $42 \%$. Similarly, the highest contribution of all the natural sources to total fine particles over land is found to be in South America by about $74 \%$ and sea-salt aerosols demonstrated to play the most important role. However, over the rest of the regions in the model domain the largest contribution from the natural sources to $\mathrm{PM}_{2.5}$ in the specific year 2006 is due to wildfires. The contribution from natural emis-
\end{abstract}

sions to the mean $\mathrm{PM}_{2.5}$ concentration over the land areas in the model domain is about $34 \%$.

\section{Introduction}

The contributions of various anthropogenic sources to air pollution levels have been a key issue in decades for policy development and regulation (Brandt et al., 2013a, b). In addition to these sources, natural emissions play an important role in determining ambient levels of harmful atmospheric pollutants, especially for tropospheric ozone and particulate matter (PM). In some cases natural emissions are even estimated to far exceed anthropogenic emissions (Olivier et al., 1996; Guenther et al., 1995). For instance, Guenther et al. (2012) estimated the annual global emissions of biogenic non-methane volatile organic compounds (BVOCs) to be $1000 \mathrm{Tg}$. This value represents about $88 \%$ of total NonMethane Volatile Organic Compound (NMVOC) emissions (Lamarque et al., 2010). Moreover, natural sources have become more important with the ongoing reductions of anthropogenic emissions and will be even more significant in the future in connection with planning of abatement strategies. Furthermore, since emission rates of natural sources often depend strongly on meteorological conditions (e.g. temperature and wind speed); their contributions to air pollution levels are expected to change in the future with a changing climate (Heald et al., 2008; Jiang et al., 2010; Hedegaard et al., 2008, 2012, 2013). Although efforts have been carried out to investigate and quantify natural emissions, the uncertainties 
and gaps with regard to these emissions are still quite large (Williams et al., 2013; Schultz et al., 2008; Guenther et al., 1995, 2012). For instance, Simpson et al. (1999) reported an uncertainty within a factor of 3-5 associated with estimation of some natural emissions in Europe. Therefore, improvement of our understanding of natural emissions and quantifying their contribution to present and future air pollution levels has been defined as an important field of research in the air pollution modeling community.

In recent years, the relative roles of natural sources in determining air pollution levels have been investigated using various methods; including chemical analysis of particles sampled from the air (e.g. Weijers et al., 2011), meteorological satellite measurements (e.g. Streets et al., 2009) and atmospheric modeling (e.g. Sartelet et al., 2012).

Modelling studies have been conducted to identify the relative contributions of different natural sources with different techniques of tracking or extracting the source contributions. Mueller and Mallard (2011), for instance, determined the specific impacts of lightning and wildfires on ozone mixing ratios over the United States using the CMAQ (Community Multiscale Air Quality) model. They found that wildfire emissions can add more than $50 \mathrm{ppbV}$ (in some cases > $90 \%$ ) to $8 \mathrm{~h}$ ozone mixing ratios from natural sources in the western US, and lightning contributes significantly to ozone levels in the southeastern US up to 25-30 ppbV (or up to about $50 \%$ ) to $8 \mathrm{~h}$ ozone mixing ratios. However, using the same chemistry transport model (CTM), Koo et al. (2010) found annual average of natural background ozone mixing ratios increase by up to $4 \mathrm{ppbV}$ over the southeastern US due to added NO from lightning. Other modelling studies have also investigated the contribution from other natural sources such as biogenic emissions on ozone and PM concentrations over Europe and North America (Zare et al., 2012; Sartelet et al., 2012). Curci et al. (2009), for instance, demonstrated that BVOC emissions lead to an enhancement of average summer daily ozone maxima over Europe by $2.5 \mathrm{ppbv}(5 \%)$.

In general, most modelling studies that have been done to investigate the role of emissions from natural sources are on the local or regional scales (Kaynak et al., 2008; Allen et al., 2012; Bossioli et al., 2012; Delon et al., 2008; Barnaba et al., 2011). More examples are studies on the role of agricultural ammonia emissions on the fine PM $\left(\mathrm{PM}_{2.5}\right)$ formation that have be done on North Carolina (Wu et al., 2008) and North America (Makar et al., 2009).

The primary objective of this modelling study is to quantify and assess the contributions from most natural emissions to ozone and fine particle concentrations particularly on a larger scale (covering more than the Northern Hemisphere). Despite the fact that some previous studies have examined the contribution of natural emissions on the global scale, they mostly focused on only one of the sources, e.g. wildfires (Jaffe and Wigder, 2012), lightning (Stockwell et al., 1999) and soil biogenic NO emission (Steinkamp et al., 2009). In this study, the individual contributions of the dif- ferent kinds of natural emissions of NMVOCs, $\mathrm{NO}_{\mathrm{x}}, \mathrm{NH}_{3}$, $\mathrm{SO}_{2}, \mathrm{CH}_{4}, \mathrm{PM}, \mathrm{CO}$, and sea salt to the total air pollution levels have been investigated for the specific year 2006. In addition, using the same air quality model gives us the ability to assess and compare the relative importance of natural sources with respect to the production of ozone and fine PM over the model domain, as well as in different regions of the Northern Hemisphere for this year.

In order to carry out a thorough investigation of natural emissions, we need to further develop the description of emissions from various sources adopted in the applied longrange chemistry transport model DEHM (the Danish Eulerian Hemispheric Model). Prior to our modifications, DEHM includes natural emissions of nitrogen oxides from soil and lightning activities, ammonia from soils, oceans, and wild animals, isoprene (among NMVOCs) from vegetation, many species from wildfires, and sea salt. Previous evaluations of the DEHM simulations against available measurements, regarding both anthropogenic and some natural sources have shown satisfying results for different chemical species, including ozone (Brandt et al., 2012; Zare et al., 2012; Solazzo et al., 2012a, b, 2013). However, in this study DEHM has been further developed to include more natural emissions of BVOCs and a scheme for describing Secondary Organic Aerosols (SOAs). Moreover, the parameterisation used for estimating sea-salt generation has been modified to contain additional features. Evaluation of the modelled total fine PM, against observations, is conducted for both the previous and new model versions to assess improvement of the model performance with the updated description of natural emissions.

Brief descriptions of DEHM with focus on the schemes for natural sources are given in the following section. Model simulations and their evaluations with respect to measurements, for the year 2006, are presented and discussed in Sect. 3. In Sect. 4, we assess the contribution of natural emissions to ozone and fine PM, and the final section contains concluding remarks and an outlook for future studies.

\section{Model description}

\subsection{The DEHM chemistry-transport model}

The air pollution model DEHM is a 3-D large-scale Eulerian atmospheric chemistry transport model with a horizontal domain covering the Northern Hemisphere and parts of the Southern Hemisphere (Christensen, 1997; Frohn, et al., 2002; Brandt et al., 2012). The model is defined on a polar stereographic projection with a resolution of $150 \mathrm{~km} \times 150 \mathrm{~km}$ true at $60^{\circ} \mathrm{N}$. In the verti$\mathrm{cal}$, the model uses a sigma-coordinate system including 29 irregular layers from the surface to $100 \mathrm{hPa}$. Anthropogenic emissions in DEHM are included from the RCP database (Representative Concentration Pathways) with a $0.5^{\circ} \times 0.5^{\circ}$ resolution for the whole domain (Lamarque et 
al., 2010), except over Europe where emissions are based on the EMEP database with a resolution of $50 \mathrm{~km} \times 50 \mathrm{~km}$ (Mareckova et al., 2008). Natural emissions are described in more details in the following subsection.

Meteorological data for running the DEHM model are derived from simulations by the mesoscale meteorological model MM5v3.7 (Grell et al., 1994), with initial and boundary conditions provided by NCEP Final Analyses (FNL) data $\left(1^{\circ} \times 1^{\circ}\right.$ spatial and $6 \mathrm{~h}$ temporal resolution).

\subsection{Natural emissions in the DEHM model}

In order to improve DEHM with a more complete description of natural emissions, we have extended the description of natural emissions with simulations of more VOC emissions (monoterpenes) from biogenic sources and subsequently SOA formation from all VOC precursors. Furthermore, this revised model includes an updated sea-salt parameterisation. Methods and databases for natural emissions from the sources, which are already implemented in DEHM, together with those updated, are described in the following.

\subsection{1 $\mathrm{NO}_{\mathrm{x}}$ from lightning}

Emissions of $\mathrm{NO}_{\mathrm{x}}$ due to lightning discharges (hereafter $\left.\mathrm{LNO}_{\mathrm{x}}\right)$ in the atmosphere are derived from the Global Emissions Inventory Activity (GEIA) database (http://geiacenter. org/presentData/lightning.html). It presents the monthly and global distributions of $\mathrm{LNO}_{\mathrm{x}}$ with a $1^{\circ} \times 1^{\circ}$ resolution, which is described by Price et al. (1997). The algorithm estimates $\mathrm{LNO}_{\mathrm{x}}$ based on the number of lightning flashes, the intensity of each flash, the lightning type (cloud-toground vs. cloud-to-cloud) and the emission factor per flash. The lightning frequencies are calculated using global cloud data from ISCCP (International Satellite Cloud Climatology Project). The global convective cloud data are provided at a $5 \mathrm{~km} \times 5 \mathrm{~km}$ spatial and 3 hourly temporal resolution for the period 1983-1990. The estimated $\mathrm{LNO}_{\mathrm{x}}$ inventory in DEHM is based on an $8 \mathrm{yr}$ average of these data. Price et al. (1997) derived the global rate of cloud-to-ground (CG) flashes of 20-30 flashes $\mathrm{s}^{-1}$, while the frequency for intracloud (IC) flashes is given as $50-70$ flashes $^{-1}$. Mean energy per flash is assumed to be $6.7 \mathrm{GJ}$ for CG flashes and one tenth of this value for IC flashes.

Using estimated $\mathrm{NO}_{\mathrm{x}}$ produced per unit energy of $10 \times 10^{16}$ (molecules $\mathrm{NO} \mathrm{J}^{-1}$ ), Price et al. (1997) found that the mean production rate of $\mathrm{LNO}_{\mathrm{x}}$ is $12.2 \mathrm{Tg} \mathrm{Nyr}^{-1}$ over the global. This estimated emission is within the range of $1-20 \mathrm{Tg} \mathrm{N} \mathrm{yr}^{-1}$ globally reported in other studies; see the review by Schumann and Huntrieser (2007).

\subsection{2 $\mathrm{NO}_{\mathrm{x}}$ from soil}

Another recognised natural source of tropospheric $\mathrm{NO}_{\mathrm{x}}$, which is included in DEHM, is biogenic soil emissions. The soil emitted $\mathrm{NO}_{\mathrm{x}}$ (hereafter SNOx) fluxes are based on an inventory by Yienger and Levy (1995), which is a function of vegetation type, temperature and precipitation. This global empirical model also includes dependence of the emission on fertilizer usage for agricultural soils, pulsing (the emissions burst following the wetting of a dry soil), biomass burning stimulation and canopy recapture of $\mathrm{NO}_{\mathrm{x}}$ (fraction of soil emitted $\mathrm{NO}_{\mathrm{x}}$ that is deposited within the canopy before it is exported to the atmosphere).

Yienger and Levy (1995) calculated the emissions every $6 \mathrm{~h}$ for one year (1990) using temperature and precipitation fields from a general circulation model. This empirical model of soil-biogenic $\mathrm{NO}_{\mathrm{x}}$ emission estimates global annual value of $5.5 \mathrm{TgN}$ above the canopy, which is in reasonable agreement with earlier simulations (Yienger and Levy, 1995). The dataset used in DEHM consists of a global $1^{\circ} \times 1^{\circ}$ distribution of monthly nitrogen oxide, which is also made available through the web site of GEIA.

\subsubsection{Ammonia from nature}

The GEIA database also provides natural as well as anthropogenic emission inventories for ammonia $\left(\mathrm{NH}_{3}\right)$. However, in this study, ammonia emissions from the anthropogenic sources are derived from the RCP database (Lamarque et al., 2010) to keep consistency. The GEIA dataset contains global ammonia emissions of domestic animals, synthetic fertilizers, biomass burning, biofuel combustion, crops, human population, fossil fuel combustion, industry, natural soils, oceans, and wild animals. The last three sources are considered as natural sources of ammonia in the model. All sources are represented globally with a $1^{\circ} \times 1^{\circ}$ resolution and monthly time resolution for the year 1990 . These emission factors are reviewed from the literature by Bouwman et al. (1997). The estimated global total ammonia emission from all sources is $54 \mathrm{TgN} / \mathrm{yr}$, in which contributions of the natural sources of soils under natural vegetation and oceans are $4 \%$ and $15 \%$, respectively. Wild animals are estimated to have a minor contribution to the global $\mathrm{NH}_{3}$ emission with total value of $0.1 \mathrm{Tg} \mathrm{N} \mathrm{yr}^{-1}$.

\subsubsection{Wildfires}

The emitted aerosols and trace gases from wildfires in DEHM include BC, OC, $\mathrm{SO}_{2}, \mathrm{CO}, \mathrm{NO}_{\mathrm{x}}, \mathrm{NH}_{3}, \mathrm{CH}_{4}$ and non-methane VOCs (ethane, ethene, propane, propene, methanol, acetaldehyde, benzene, toluene, xylene, isoprene, and monoterpenes). Emissions of gases and carbonaceous particles from vegetation fires are taken from the RETRO inventory (REanalysis of the TROpospheric chemical composition over the past 40 years; Schultz et al., 2007). The database provides the global emissions with $0.5^{\circ} \times 0.5^{\circ} \mathrm{spa}-$ tial resolution and monthly time resolution over a long period (from 1960 to 2000). The approach is based on aggregated estimates of total carbon emissions. The emission rate 
of every compound is given by

$$
E(i)=A \times E_{\text {net }}(C) \times E R(i, C)
$$

where $E R$ is the emission ratio of compound $i$ relative to the total carbon, $A$ is the burned area and $E_{\text {net }}$ is the average amount of carbon per unit area. This emission factor and the burned area are dependent on the geographical region and ecosystem type. Interannual variability of emissions in the RETRO is driven only by variations in the burned area.

In RETRO, the Regional fire model (Reg-FIRM) is used to provide estimates of the burned area variability based on the climate data (Venevsky et al., 2002). Schultz et al. (2008) displayed that the geographical distribution of monthly meantotal carbon emissions from open fires for a particular year are rather consistent with the values obtained by the Global Fire Emission Database (GFEDv2; van der Werf et al., 2006), which is based on satellite data. Inventory of GFED version 3 (van der Werf et al., 2010) provide an improved satellitederived estimates of burned area and fire activity for the past decade to decrease the large uncertainty in fire emissions estimates. However, the RETRO dataset is used in this study, for consistency of the DEHM version with the one used in the study of Brandt et al. (2012), Zare et al. (2012) and Solazzo et al. (2012a, 2013) regards to ozone concentrations. The recent studies have thoroughly evaluated the ozone concentrations with measurements from Europe and North America.

\subsubsection{Biogenic VOCs (BVOCs)}

BVOCs contribute together with nitrogen oxides to change the ozone budget on regional and global scales. Moreover, BVOCs play a key role in the formation of SOAs (Tsigaridis and Kanakidou, 2003), which can appear to be the major constituent of the atmospheric particulate matter over some regions (Mueller and Mallard, 2011). Therefore, estimation of BVOC as the biogenic precursors of air pollutants is significant when aiming at quantifying impacts of the natural emissions on the atmospheric pollution.

BVOCs consist of a wide variety of compounds. Among them, isoprene is the most abundant one (Guenther et al., 1995) and is an important species for the ozone formation (Atkinson, 2000). In this paper, the focus is also on another BVOC class, namely monoterpenes (MTs). MTs are isomers of two isoprene units, i.e. they are very reactive with short atmospheric lifetime, and as well as isoprene can contribute to production of organic particles.

Recently, Zare et al. (2012) described an updated version of DEHM including isoprene emissions using MEGAN (Model of Emissions of Gases and Aerosols from Nature; Guenther et al., 2006). MEGAN estimates an ecosystem dependent emission rate of isoprene based on empirical relationships between key drivers (temperature $\left(Q_{T}\right)$ and radiation $\left(Q_{\mathrm{PAR}}\right)$, leaf area index $\left(Q_{\mathrm{LAI}}\right)$, foliage age $\left(Q_{\mathrm{age}}\right)$ and soil moisture $\left.\left(Q_{\mathrm{SM}}\right)\right)$. The current study uses also PCEEA algorithm of MEGAN to calculate hourly emission rates of
MTs. However, the model characterises the light and temperature dependence of MTs based on an alternative emissions process. MTs have the ability to be stored in the plant and emitted from these stored pools. However, they are also emitted immediately after production similar to isoprene (Laothawornkitkul et al., 2009). On the canopy scale, there are combinations of both types of mechanisms. Therefore, the MT emission rates $(E)$ in MEGAN are parameterised using lightdependence fraction (LDF):

$$
\begin{aligned}
& E=E_{0} \times Q_{\mathrm{age}} \times Q_{T} \times Q_{\mathrm{LAI}} \times Q_{\mathrm{SM}} \\
& \times\left[(1-\mathrm{LDF})+Q_{\mathrm{PAR}} \times \mathrm{LDF}\right]
\end{aligned}
$$

in which $E_{0}$ is the basal emission normalised to standard conditions. The compound-dependent LDF shows the fraction of MT emissions influenced by variations in light levels. MEGAN calculates emission rates for seven monoterpene compounds (alpha-pinene, beta-pinene, limonene, myrcene, sabinene, delta3-carene and ocimene). The activity factor $Q_{T}$ accounts for the effect of variations in temperature on MT emissions as described by Guenther et al. (1995):

$Q_{T}=B \times \exp \left(T-T_{\mathrm{s}}\right)$

where $T_{\mathrm{S}}$ is a standard temperature and $B$ is a temperature dependent parameter $\left(\mathrm{K}^{-1}\right)$ with the value of 0.13 for MTs (Sakulyanontvittaya et al., 2008). Other activity factors are parameterised similar to those for isoprene.

\subsubsection{Secondary organic aerosols}

In this study, the DEHM model has been further developed, by including a module for SOA treatment. We follow the idea of the two-product approach for SOA formation described by Chung and Seinfeld (2002). This partitioning scheme assumes that parent hydrocarbons undergo oxidation via reaction with $\mathrm{O}_{3}, \mathrm{OH}$ and $\mathrm{NO}_{3}$ and form only two semivolatile gas products. The empirical values of equilibrium gas-particle partitioning coefficients and stoichiometric coefficients together with the oxidation rate for VOCs are given by Chung and Seinfeld (2002) for MTs, by Henze and Seinfeld (2006) for isoprene, and by Tsigaridis and Kanakidou (2003) for aromatics. The partitioning coefficients are calculated by the Clausius-Clapeyron equation and the enthalpy of vaporization of $42 \mathrm{~kJ} \mathrm{~mol}^{-1}$ is used for all products (Chung and Seinfeld, 2002; Hoyle et al., 2007).

The products of oxidation via $\mathrm{OH}$ and $\mathrm{O}_{3}$ are considered together and oxidation with $\mathrm{NO}_{3}$ is considered only for MTs and it is assumed to produce only one yield (Griffin et al., 1999). The concentration of the oxidation products in the gas phase (SOG) is calculated based on the partitioning theory (Pankow, 1994):

$\mathrm{SOG}_{i, j, k}=\mathrm{SOA}_{i, j, k} /\left(K_{i, j, k} \times M_{0}\right)$

where $\mathrm{SOA}_{i, j, k}$ is the aerosol concentration of the $k^{\text {th }}$ product from the reaction of hydrocarbon $i^{t h}$ and oxidant $j^{t h}$; 
$K_{i, j, k}$ is its partitioning coefficient. $M_{0}$ consists of both primary organic aerosols (POAs) and SOAs. These are calculated by an iterative approach.

This model has some limitations, e.g. it does not include aging processes and further reactions in the gas and particulate phase. However, we use this approach in our study because the model combines simplicity with the ability to accurately reproduce the laboratory measurements. In this method, POAs are considered as non-volatile, non-reactive and only served as a surface for the condensation of SOAs. Recently, the Volatility-Basis-Set approach (VBS) is introduced for taking into account the volatility of POAs (Robinson et al., 2007; Donahue et al., 2006). Using VBS in recent modelling studies has increased the amount of SOAs in polluted regions, which shows a good agreement with measurements in megacity environments (Hodzic et al., 2010). Since VBS expands the 2-product model to consider many volatility bins, it is therefore not computationally advantageous for the current assessment study with focus on the background and natural emissions. Additionally, in this simulation, the light absorbing and scattering properties of SOAs and the impacts on the model photolysis rate are not taken into account.

\subsubsection{Sea salt}

Sea-salt aerosol can significantly enhance constituent of particulate matter in coastal areas (Pryor et al., 2007). In air quality models, the generation of sea spray is described with source functions, which parameterise sea-salt production in terms of some variables. Parameters like wind speed, the thermal stability of the atmospheric and ocean surface layer, salinity and sea-water temperature can influence the flux intensity and size distribution of sea spray (de Leeuw, et al., 2000).

Currently, production of sea salt in DEHM has been modelled only as a function of wind velocity at the height of $10 \mathrm{~m}$ $\left(U_{10}\right)$. The method is derived based on a simplified parameterisation by Monahan et al. (1986), which calculate the production of aerosol $(P)$ by:

$P=0.007 \times\left(U_{10}\right)^{3.14}$

This parameterisation considers the mechanism of bubble bursting for sea-salt aerosol generation. Since the DEHM model, using this module, underestimates measured sodium concentrations, the emission algorithm has been revised to consider a wider range of particles sizes. In the new version, the diameter of dry particles is expanded in the range from 0.02 to $6 \mu \mathrm{m}$ and two different parameterisation schemes are used for calculating sea spray generation in this interval. We use a source function from bubble-mediated presented by Mårtensson et al. (2003) to produce flux estimates of sea salt with dry diameter up to $1.25 \mu \mathrm{m}$. Mårtensson et al. (2003) show that the sea spray generation function $(F)$ is not only dependent on the surface wind but also takes into account the variation of whitecap coverage with sea water tempera- ture $\left(T_{\mathrm{w}}\right)$ and salinity:

$F=3.84 \times 10^{-6} \times U_{10} \times\left(A_{k} T_{\mathrm{w}}+B_{k}\right)$

where $A_{k}$ and $B_{k}$ parameters show the dependence of seasalt flux on the aerosol size. In the new version of DEHM, the Monahan et al. (1986) parameterisation of sea-salt emission is used for the rest of particles with larger sizes. This second scheme is a source function, which calculates the rate of sea-salt droplet generation $(F)$ of the aerosol radius at $80 \%$ relative humidity $(r)$ by:

$$
\begin{aligned}
& F=1.373 \times\left(U_{10}\right)^{3.14} \times r^{-3} \\
& \times\left(1+0.057 r^{1.05}\right) \times 10^{1.19 \exp \left(-b^{2}\right)}
\end{aligned}
$$

in which $b=(0.380-\log (r)) / 0.650$. The used relationship between the dry and wet $(r)$ radius is based on Gong et al. (1997).

In the next section, DEHM is evaluated for both the previous and new parameterisations to investigate how much the model is improved.

\section{Updating natural emissions in DEHM}

Before assessing the impact of natural sources on the air quality levels, we have conducted a series of simulations for monoterpenes and SOA formation using the revised version of DEHM. The simulations of these compounds are evaluated against the available measurements in the model domain. Moreover, the model results with the updated seasalt emissions are evaluated, and performance of the revised model is compared with that of the recent version.

\subsection{Simulation of monoterpenes from vegetation}

The hourly biogenic concentrations of MTs $\left(\mathrm{C}_{10} \mathrm{H}_{16}\right)$ are simulated by integrating MEGAN into the DEHM model. The described MEGAN algorithm estimates emissions of all seven MT classes on the same domain and resolution as in DEHM. The spatial distribution of the annual MT mixing ratios, which is the sum of the seven compounds is shown in Fig. 1. The simulated mixing ratios are displayed for the year 2006 in the lowest model layer (thickness of around $12 \mathrm{~m}$ ) over an extended area of the Northern Hemisphere. The highest mixing ratios with values above $0.6 \mathrm{ppbV}$ are simulated over the tropics where large biomass densities and markedly warm regional climate are combined. These key factors can also explain higher mixing ratios throughout the summertime in the rest part of Northern Hemisphere. For instance, Fig. 1 also shows considerable mixing ratios at higher latitudes in the boreal forest areas, which are covered by coniferous (softwood) trees such as pines and firs with high MT emissions in summer.

Figure 2 shows monthly emission rates $\left(\mathrm{Tg} \mathrm{month}^{-1}\right)$ for each MT compound together with cumulative total. One can 
Table 1. Comparison of the mean (M) monoterpenes mixing ratios (ppbV) between observed and calculated data by DEHM, using the MEGAN biogenic model, for the time periods corresponding to the measuring period at the individual sites. The evaluations for the sites in the US and in Europe are performed using statics parameters of the correlation coefficient (Corr.) and the fractional bias (FB). H is the height of the station above sea-level.

\begin{tabular}{|c|c|c|c|c|c|c|c|c|c|}
\hline Location & Number of observations & Lat. & Long. & $\mathrm{H}(\mathrm{m})$ & Measuring period & M-Obs & M- Model & Corr. & FB \\
\hline Finland/Hyytiälä & 1292 & $61.51^{\circ} \mathrm{N}$ & $24.17^{\circ} \mathrm{E}$ & 180 & 2006 & 0.26 & 0.23 & 0.85 & -0.08 \\
\hline Belgium/Vielsalm & 2564 & $50.30^{\circ} \mathrm{N}$ & $5.99^{\circ} \mathrm{E}$ & 450 & Mar-Sep 2010 & 0.09 & 0.06 & 0.64 & -0.43 \\
\hline Massachusetts/ Petersham & 880 & $42.54 \mathrm{~N}$ & $72.17 \mathrm{~W}$ & 340 & summer 2005 & 0.18 & 0.22 & 0.34 & 0.19 \\
\hline
\end{tabular}

Table 2. Comparison of the mean (M) monoterpenes mixing ratios (ppbV) between observed and calculated data by DEHM, using MEGAN biogenic model, for the measuring period 2004-2009. The evaluations for the 6 years individually at Thompson Farm in Durham, New Hampshire (US) (Haase et al., 2011) are performed using statistics of the correlation coefficient (Corr.) and the fractional bias (FB).

\begin{tabular}{llllll}
\hline $\begin{array}{l}\text { Measuring } \\
\text { period }\end{array}$ & $\begin{array}{l}\text { Number of } \\
\text { observations }\end{array}$ & M-Obs & M- Model & Corr. & FB \\
\hline 2004 & 721 & 0.93 & 0.19 & 0.57 & -1.32 \\
2005 & 3602 & 0.88 & 0.15 & 0.69 & -1.41 \\
2006 & 5434 & 0.33 & 0.1 & 0.44 & -1.09 \\
2007 & 5110 & 0.39 & 0.11 & 0.71 & -1.11 \\
2008 & 6471 & 0.37 & 0.09 & 0.73 & -1.22 \\
2009 & 4075 & 0.36 & 0.10 & 0.52 & -1.12 \\
\hline
\end{tabular}

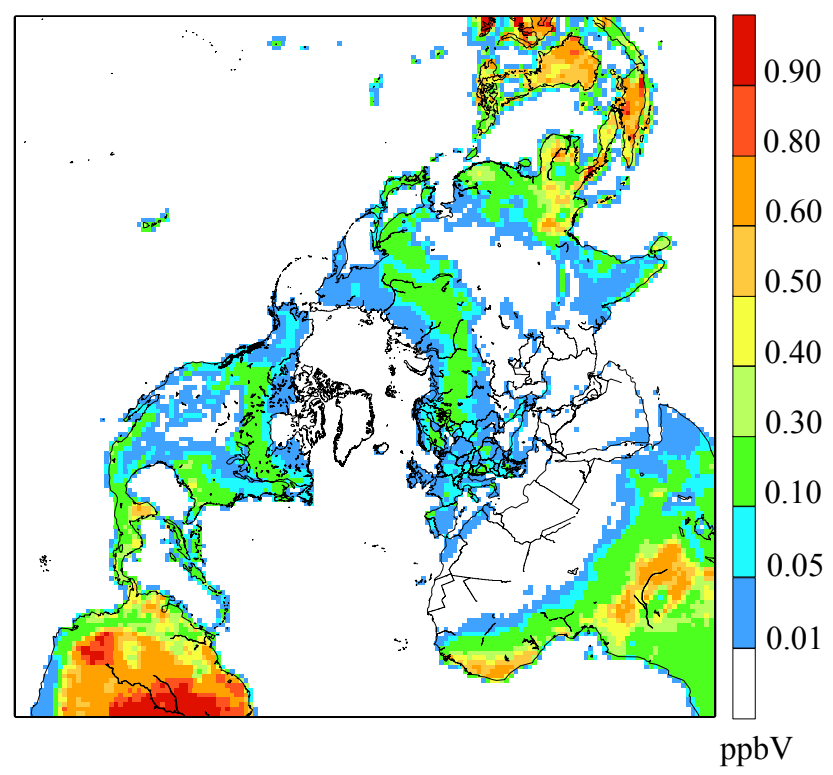

Fig. 1. Spatial distribution of the annual average monoterpenes mixing ratios (ppbV) simulated by DEHM in the lowest model layer using the MEGAN biogenic emission model for 2006.

see the emissions peak in July, which occurs due to strong temperature dependency of MT emissions. The total annual emission of MTs in the studied area (from $10^{\circ} \mathrm{S}$ to $90^{\circ} \mathrm{N}$ ) is estimated to $88.4 \mathrm{Tg}$, which is consistent with previous stud-

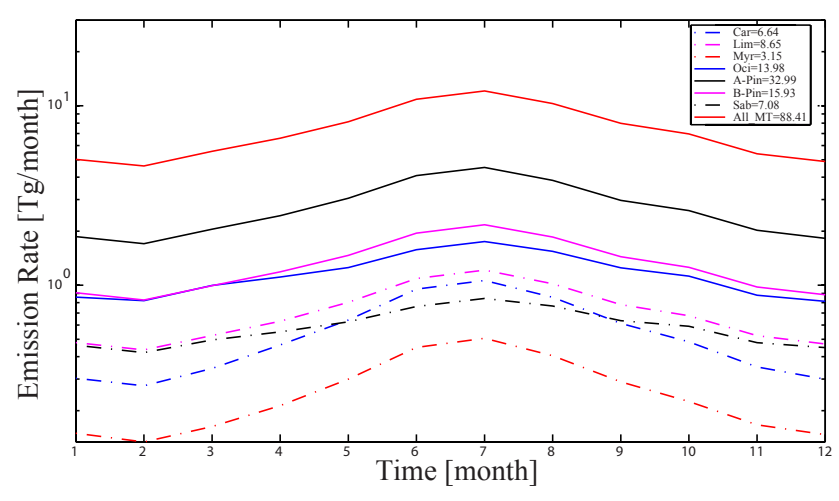

Fig. 2. Monthly emission rates $\left(\mathrm{Tg} \mathrm{month}^{-1}\right)$ for seven monoterpene compounds (alpha-pinene, beta-pinene, limonene, myrcene, sabinene, delta3-carene and ocimene), together with cumulative total (All) calculated by MEGAN, in a domain covering the Northern Hemisphere, for 2006. Annual fluxes (Tg) of each compound are also given.

ies of e.g. Guenther et al. (1995). This value is lower compared to isoprene emissions, which has a total emission of $592 \mathrm{Tg} \mathrm{year}^{-1}$ in the same domain (Zare et al., 2012). With respect to individual MTs, $\alpha$-pinene shows the highest contribution to the total MTs throughout the year, followed by $\beta$-pinene and ocimene.

The evaluations of DEHM for simulated MT mixing ratios against measurements from four different sites in the US (two sites) and in Europe (two sites) are summarised in Tables 1 and 2. In Table 1, the DEHM model results are compared with measurements from Hyytiälä, in southern Finland $\left(61.51^{\circ} \mathrm{N}\right.$ and $24.17^{\circ} \mathrm{E}$, Taipale et al., 2008), Vielsalm in Belgium $\left(50.30^{\circ} \mathrm{N}\right.$ and $5.99^{\circ} \mathrm{E}$, Laffineur et al., 2011), and Harvard Forest in Petersham, MA $\left(42.54^{\circ} \mathrm{N}\right.$ and $72.17^{\circ} \mathrm{W}$, McKinney et al., 2011). These three measurement sites are located in vegetation and/or forest zones in rural areas. The simulations are carried out in time periods corresponding to the periods of measurements in the individual sites. The fourth monitoring site is located at Thompson Farm in Durham, New Hampshire $\left(43.10^{\circ} \mathrm{N}\right.$ and $\left.70.99^{\circ} \mathrm{W}\right)$ where the measurements were made in open agricultural fields from 2004 to May 2009 (Haase et al., 2011). Table 2 shows the simulations compared with observations for each year covering the entire period at the site. At all the four 

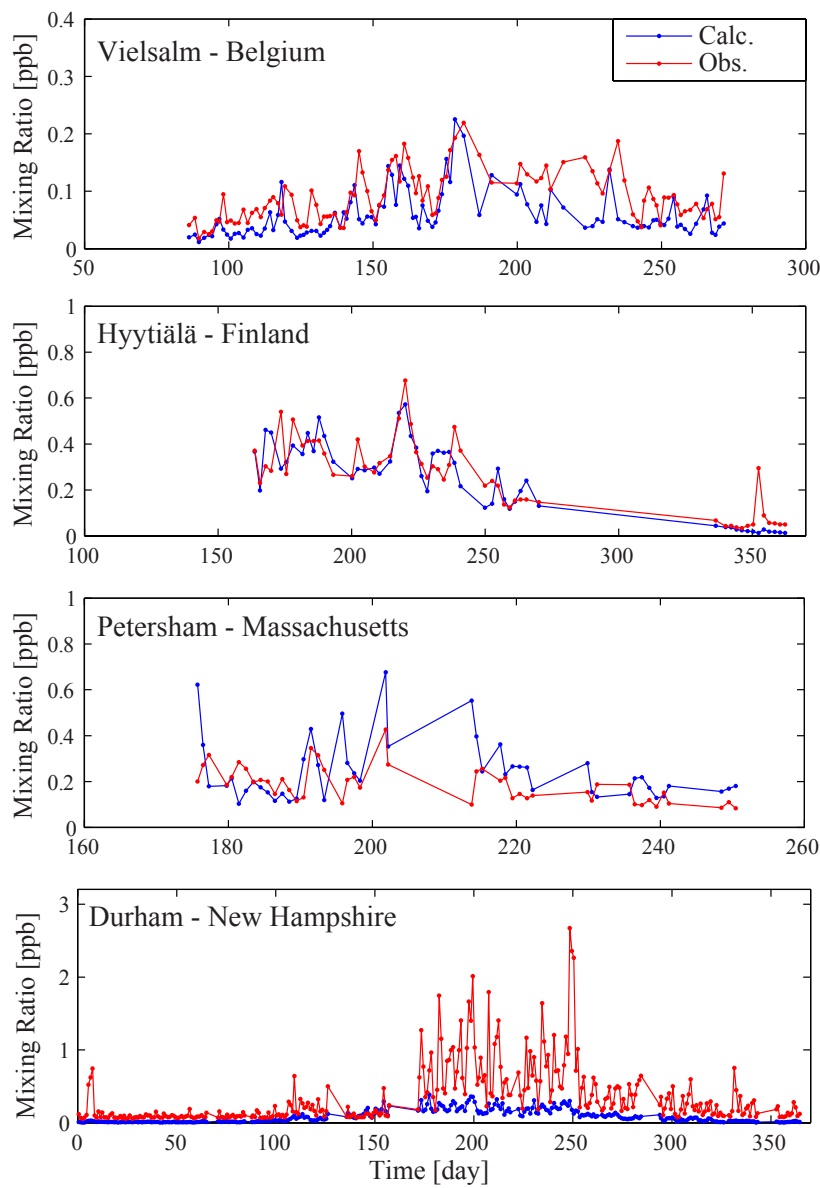

Fig. 3. Validation of the DEHM model results of daily average monoterpene mixing ratios against measurements from the sites in Belgium, Finland, Massachusetts and New Hampshire for the years 2010, 2006, 2005 and 2008 respectively.

sites, the atmospheric mixing ratios of MTs are measured using the technique of proton transfer reaction mass spectrometry (PTR-MS). Since PTR-MS determines only the mass of the product ions, it is impossible to distinguish between different VOCs within the same mass. The signal at $137 \mathrm{~m} / \mathrm{z}$ is attributed to the total mixing ratio of MT compounds (Laffineur et al., 2011). The performance of DEHM with respect to the MT mixing ratios is evaluated according to the correlation coefficient and the fractional bias in Tables 1 and 2. However, in Fig. 3, we display the temporal variations of the simulated mean daily MT mixing ratios against observations at the sites during their corresponding measuring periods and years; for the station in Durham, the year 2008 is shown as an example.

The modelled mean daily mixing ratios of MTs in Hyytiälä, Finland, show a high correlation (0.85) and a small fractional bias $(-0.08)$ compared with measurements. However, the model does not capture the high mixing ratio episode at the end of the simulation period. The model sim- ulations are correlated with the measurements in the range of $0.34-0.85$. Although the calculated correlation coefficient of 0.34 for the Harvard Forest site shows the timing of the emission is quite different, in general these results for all sites are satisfactory considering the relatively coarse model resolution in this simulation and also difficulty in accurately evaluation of the short-lived BVOCs against measurements. Kanakidou et al. (2005) estimated that the uncertainties in global terpene emissions could be as high as a factor of 5 . However, comparison of the mean mixing ratios between the observed and calculated data in Table 1 indicates that the simulated mixing ratios are in good agreement with the measurements for these three sites. Table 2 shows that the model underestimates MTs for the monitoring site in Durham. Uncertainties in the emission algorithm, modelling of chemical pathways and meteorological inputs together with experimental uncertainties (McKinney et al., 2011) could result in this discrepancy. Furthermore, the underestimation of MTs at the Durham site could be due to small MT emission factors used in MEGAN for that region. For instance, Sakulyanontvittaya et al. (2008) showed that MT fluxes are lower with MEGAN compared to another Biogenic Emission Inventory System (BEIS3.0) in most regions in North America. However, the underestimation at this site could also be due to stronger local sources, which cannot be captured by the relatively course resolution of the model.

\subsection{Simulation of SOA formation}

Figure 4 shows monthly mean concentrations of SOA simulated by DEHM for January and July 2006. The concentrations are higher over the tropical rainforest, in South America, Africa and Southeast Asia, exceeding $1.5 \mu \mathrm{g} \mathrm{m}^{-3}$ level during both January and July. In other words, the tropics has just a small seasonal cycle, however, southeastern United States and Europe are demonstrated with relatively high SOA concentrations only in the summer time. The geographical distribution of SOA reflects the distribution of the precursor emission. Large concentrations of SOA in July are due to larger biogenic emissions resulted from higher temperatures. On the other hand, high tropical large SOA concentrations in January are due to efficient conversion of oxidized precursors to the aerosol form in wintertime. This is because the SOA condensation is favoured at cold temperatures. In the boreal regions in summer, monoterpenes mostly contribute to SOA formation. Generally, we have estimated the annual total SOA production of $5.8 \mathrm{Tg}$ over the model domain. The total global production of SOAs is a very uncertain quantity. A range of about $2 \mathrm{Tg}_{\text {year }}{ }^{-1}$ to $70 \mathrm{Tg}_{\text {year }}{ }^{-1}$ of total global SOA formation is given in previous modelling studies (Hoyle et al. 2007; Tsigaridis and Kanakidou, 2003; Chung and Seinfeld, 2002).

In order to study the contributions of secondary organic aerosols to the total concentrations of organic aerosols $(\mathrm{OA}=\mathrm{POA}+\mathrm{SOA})$, the mean annual concentrations of 

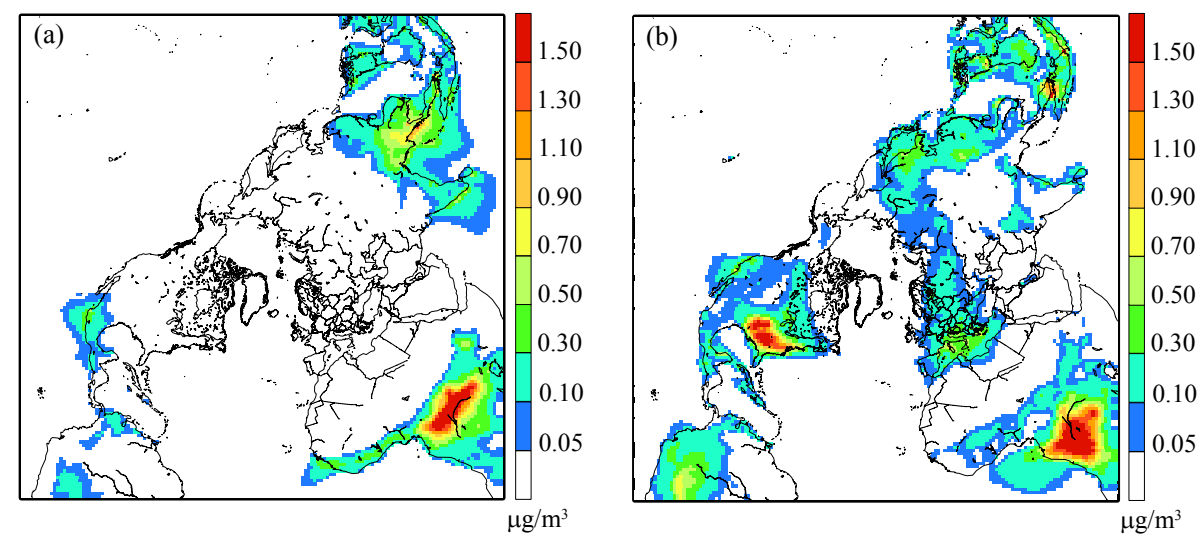

Fig. 4. The surface-layer concentrations $\left(\mu \mathrm{g} \mathrm{m}^{-3}\right)$ of SOAs in January and July simulated by DEHM based on two-product approach for SOA formation in 2006.
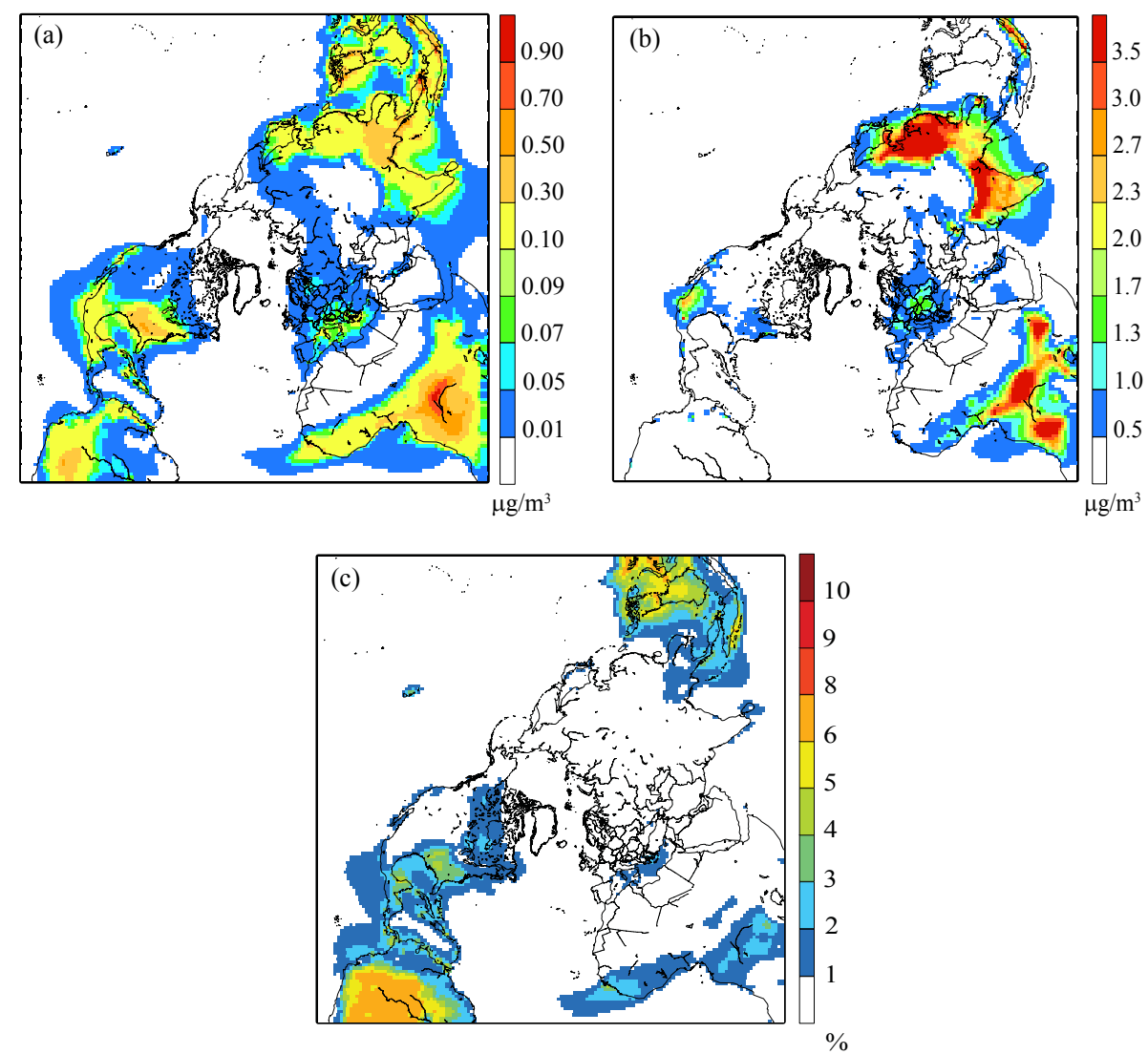

Fig. 5. Geographical distributions of annual average (a) SOA and (b) POA concentrations $\left(\mu \mathrm{g} \mathrm{m}^{-3}\right)$ simulated by DEHM for the year 2006. (c) shows the ratios of SOAs to total OAs (POAs+SOAs).

SOAs and POAs, together with the ratio of SOAs in the total $\mathrm{OA}$ are shown in Fig. 5. We find that the largest contribution of SOAs to the total organic aerosols (OAs) is $8 \%$, which occurs in South America. Although this contribution is not high considering the annual average, it becomes dominant (above $70 \%$ ) over part of the tropics and the southeastern part of the US in the summertime (not shown). This is due to the fact that the highest emissions of BVOCs, as SOA precursors, occur during the summer period. The major fraction of the total OAs over Europe and Asia, however, consists of POA. Regards to distribution of the annual SOA concentrations, the highest values are seen in the regions with the highest emissions of precursors such as equatorial regions (Fig. 5a). However, the availability of POAs as a surface for condensation of 


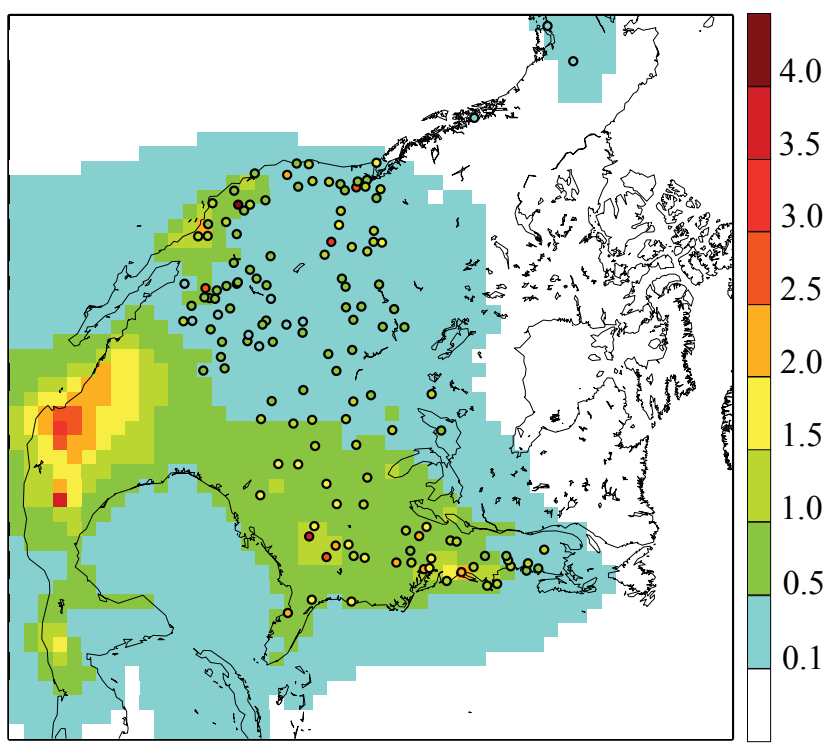

$\mu \mathrm{g} / \mathrm{m}^{3}$

Fig. 6. Spatial distribution of simulated annual average concentration $\left(\mu \mathrm{g} \mathrm{m}^{-3}\right)$ of OAs (primary and secondary OAs) against measurements (circles) from sites in the IMPROVE network, for 2006.

SOAs also plays an important role in the distribution of SOA concentrations. The emissions of primary organic aerosols are considered in DEHM from fossil fuel and biofuel combustion as well as biomass burning sources with a total value of $24.4 \mathrm{TgC}$ year $^{-1}$. Therefore, the POA concentrations are high in relatively polluted regions such as parts of Asia and Europe, and regions with strong wild fires such as Africa's savannah and equatorial regions (Fig. 5b).

In order to evaluate the model performance, spatial and temporal distributions of simulated OA are compared against measurements from the ground-based network of the Interagency Monitoring of Protected Visual Environments (IMPROVE) (http://http://vista.cira.colostate.edu/improve/). Figure 6 shows that DEHM reasonably reproduces the observed spatial distribution of OAs over North America with higher values over the eastern part. However, an underestimation of OA concentration is found at a number of sites. The annual mean value for all stations is estimated to be $0.43 \mu \mathrm{g} \mathrm{m}^{-3}$, which is lower than the observed mean value of $1.02 \mu \mathrm{g} \mathrm{m}^{-3}$. This discrepancy might be explained by the underestimation of either POAs or precursors of SOAs by MEGAN. In addition to, uncertainties accompanied by simulation of partitioning between the gas and particle phases as well as simulated meteorological parameters can be sources of the underestimation. However, as seen in Fig. 7, the model shows high skill in simulating the daily variability with a high correlation coefficient of 0.81 , and a good ability to capture most of the observed variations. In general, considering large uncertainties related to simulating SOAs, this compari-

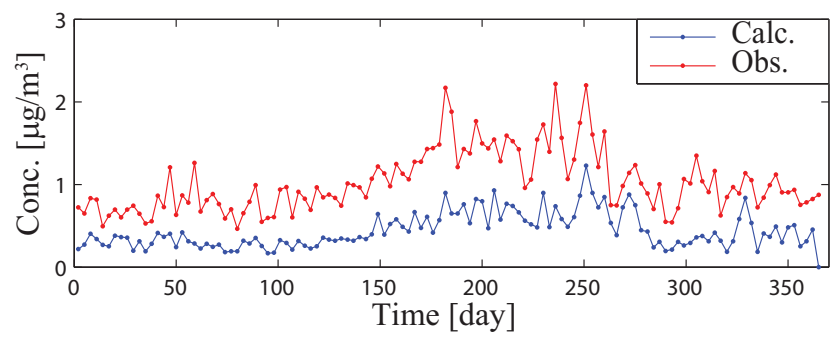

Fig. 7. Daily mean values of the simulated OA concentrations against observations from the IMPROVE network, taken as an average over the sites shown in Fig. 6.

son concludes that the model perform relatively well in simulating OAs over the US.

Results for the evaluation of OA concentrations in Europe are presented in Table 3. The table summarises the model performance statistics for some stations from the EMEP network with available data for the year 2006. The results show that the model underestimates OA concentration over Europe, probably due to the underestimation of POA and/or BVOC emissions in this area. However, some studies indicate that our understanding of SOA forming processes is insufficient. Recent laboratory experiments have suggested the incorporation of additional atmospheric processes such as further oxidation, formation of organosulfates and oligomerization to form more SOAs (Muller et al., 2012; Kristensen et al., 2013; Emanuelsson et al., 2013). As an example, Hall and Johnston (2010) estimated that formation of oligomers can contribute as much as $50 \%$ to the non-volatile SOA mass, and Hoyle et al. (2009) demonstrated that the annual mean SOA burden increased about $59 \%$, when allowing semivolatile species to partition to sulphate aerosol. The increase is greatest over industrial areas as well as over regions with high emissions of biogenic precursors (Hoyle et al., 2009; Spracklen et al., 2011). This can particularly elucidate the highest discrepancy of simulated OAs compared to measurements for the two background sites in Italy (Table 3). The stations are located close to metropolitan and industrial cities as well as adjacent the area with the large BVOC emissions in Europe (Zare et al., 2012).

\subsection{Sea-salt simulation}

Figure 8 shows the annual mean spatial distribution of seaspray aerosols from DEHM calculated by a combined source functions based on Mårtensson et al. (2003) and Monahan et al. (1986). Sea-salt emissions peak in the central parts of the major oceans mainly due to the higher wind speeds in winter. However, in summertime higher sea surface temperatures result in increased particle emissions. Despite that sea salt is a dominant aerosol type over the oceans, the particles can be transported inland with onshore winds and significantly affect the air quality in the coastal areas as well. Here seasalt simulation from the revised DEHM model is evaluated 
Table 3. Comparison of the mean (M) simulated OA concentrations $\left(\mu \mathrm{g} \mathrm{m}^{-3}\right)$ with observations in Europe in sites from the EMEP network with available data for the year 2006. The model performances based on two-product approach for SOA formation are evaluated by statistic parameters (correlation coefficient (Corr.) and the fractional bias (FB)).

\begin{tabular}{lllllll}
\hline Country/site & Latitude & Longitude & M_Obs & M_Model & Corr. & FB \\
\hline Italy/Ispra & $45.48^{\circ} \mathrm{N}$ & $8.38^{\circ} \mathrm{E}$ & 8.79 & 1.27 & 0.39 & -1.49 \\
Italy/Montelibretti & $42.06^{\circ} \mathrm{N}$ & $12.38^{\circ} \mathrm{E}$ & 6.16 & 0.89 & 0.82 & -1.49 \\
Schwitzerland/Payerne & $46.48^{\circ} \mathrm{N}$ & $6.57^{\circ} \mathrm{E}$ & 2.68 & 0.65 & 0.52 & -1.22 \\
Austria/Illmitz & $47.46^{\circ} \mathrm{N}$ & $16.46^{\circ} \mathrm{E}$ & 2.31 & 0.60 & 0.45 & -1.16 \\
Germany/Melpitz & $52.31^{\circ} \mathrm{N}$ & $12.55^{\circ} \mathrm{E}$ & 2.07 & 0.89 & 0.57 & -0.79 \\
Spain/Montseny & $41.45^{\circ} \mathrm{N}$ & $2.35^{\circ} \mathrm{E}$ & 1.82 & 0.84 & 0.54 & -0.73 \\
Norway/Birkenes & $58.23^{\circ} \mathrm{N}$ & $8.15^{\circ} \mathrm{E}$ & 1.04 & 0.41 & 0.42 & -0.86 \\
\hline
\end{tabular}

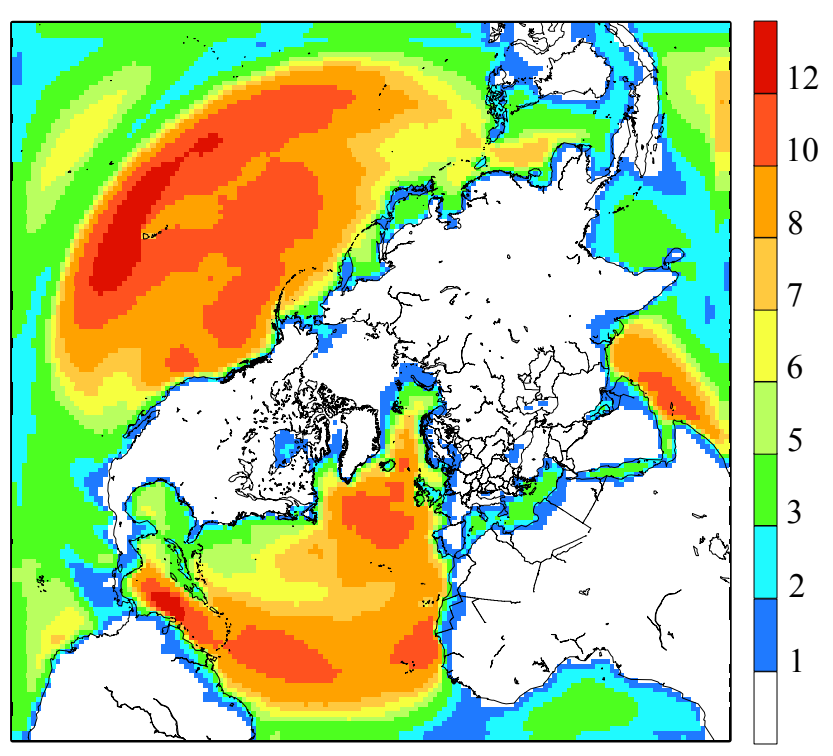

$\mu \mathrm{g} / \mathrm{m}^{3}$

Fig. 8. Annual mean concentrations $\left(\mu \mathrm{g} \mathrm{m}^{-3}\right)$ of sea salt in 2006 calculated by DEHM using combined source functions based on Mårtensson et al. (2003) and Monahan et al. (1986).

against observations from the coastal sites over Europe. We use the measurements of sodium concentrations provided at 23 stations from the EMEP monitoring network in the year 2006. Sodium is a reliable tracer for sea salt since it is not subject for chemical reactions, contrary to chloride (Dasgupta et al., 2007). Since the sodium mass fraction of sea salt is 0.306 (Seinfeld and Pandis, 2006), total sea salt from observations is calculated as a product of sodium times 3.26. Figure $9 \mathrm{a}$ and $\mathrm{b}$ shows an evaluation of old and new model results, respectively, compared to measurements on a daily basis for the year 2006 as a mean over the EMEP stations. Compared to the model results obtained using the previous version (Fig. 9a), using the revised algorithm for sea salt improves the performance of DEHM considerably (Fig. 9b). The revised version captures most of the sea-salt episodes, and leading to a very small bias. However, using both schemes result in relatively good correlation coefficients between modeled and measured sea-salt concentrations (i.e. 0.78 and 0.80 ).

Subsequently, we present how much the simulated total $\mathrm{PM}_{2.5}$ concentration in Europe from DEHM is improved by including these revised natural emissions. Performances of the revised and previous versions of DEHM for total $\mathrm{PM}_{2.5}$ are compared against measured data from 22 EMEP sites (Fig. 10). The total particle concentrations in this evaluation are based on emissions from both anthropogenic and natural sources, and consist of black carbon (fresh and aged), organic carbon (primary and secondary), sea salt and secondary inorganic aerosols (SIAs) $\left(\mathrm{SO}_{4}^{2-}, \mathrm{NO}_{3}^{-}, \mathrm{NH}_{4} \mathrm{NO}_{3}\right.$, $\mathrm{NH}_{4} \mathrm{HSO}_{4}$ and $\left.\left(\mathrm{NH}_{4}\right)_{2} \mathrm{SO}_{4}\right)$. In the revised version with including SOAs and the alternative sea-salt emissions, the results of simulated total fine particle concentrations are improved. The annual average value slightly increases from $5.8 \mu \mathrm{g} \mathrm{m}^{-3}$ to $6.4 \mu \mathrm{g} \mathrm{m}^{-3}$ and fractional bias between the results of the further developed model and observations is also improved $(\mathrm{FB}=-0.67)$ compared to the previous version of DEHM $(\mathrm{FB}=-0.75)$. We can conclude from the results that using the new combined source function for sea salt simulation and also adding a scheme for SOA formation make a relatively better agreement with total fine PM observations on the European scale. However, the contribution of using the revised algorithm for sea-salt simulation with regard to the improvement of $\mathrm{PM}_{2.5}$ simulation is more considerable compared to the SOA simulation improvement in this study. Nevertheless, in general, DEHM still underestimates the total observed aerosol concentrations. Model evaluations for some individual compounds in DEHM show that the simulated secondary inorganic aerosols (Brandt et al., 2012) and sea salt (Fig. 9) are in a good agreement with measurements. Limitations of the current model performance for fine particles in Europe can partly be related to missing windblown dust in this study and/or the underestimation of SOA concentrations (Fig. 7). However, accompanied uncertainties with emissions of black carbon and primary organic carbon from anthropogenic sources and biomass burning, especially in winter time, can also be the other sources of the 


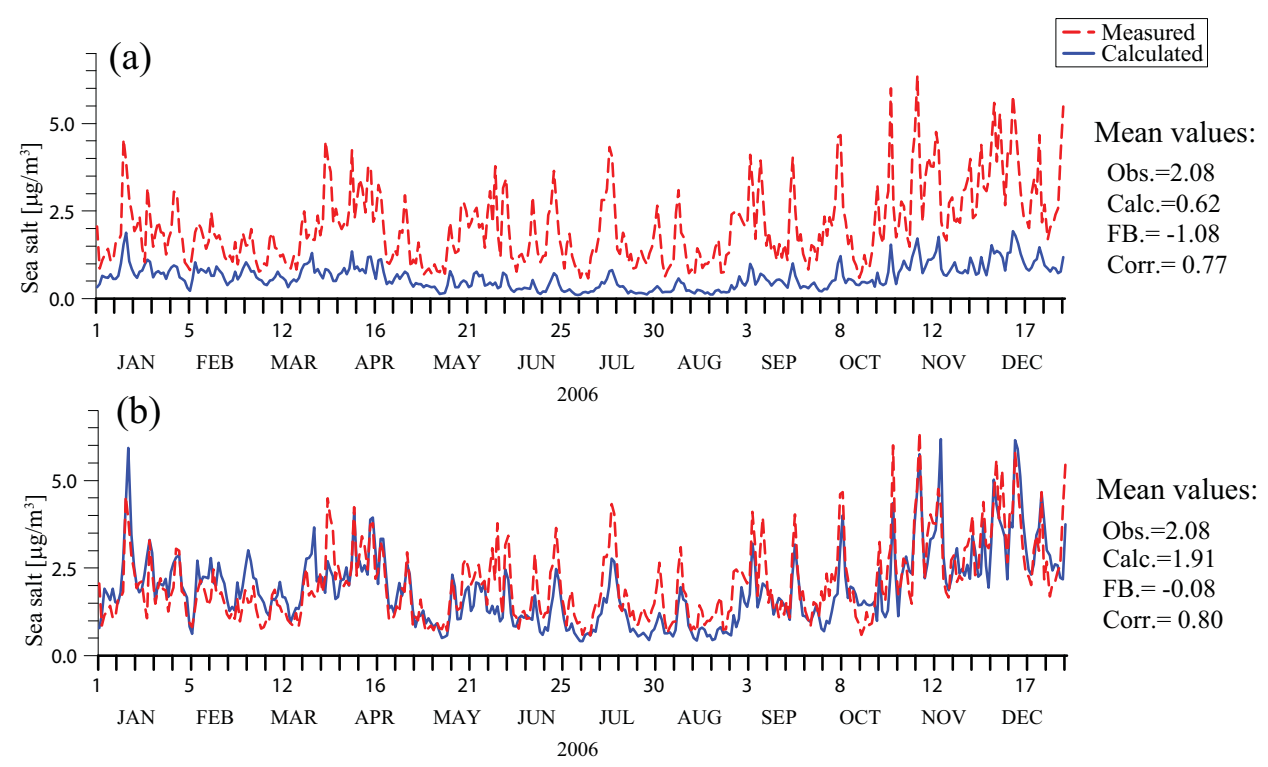

Fig. 9. Evaluation of the sea-salt simulations from DEHM based on (a) a simplified parameterisation by Monahan et al. (1986), and (b) a combined source function based on Mårtensson et al. (2003) and Monahan et al. (1986) against observations from the EMEP monitoring network in the year 2006.

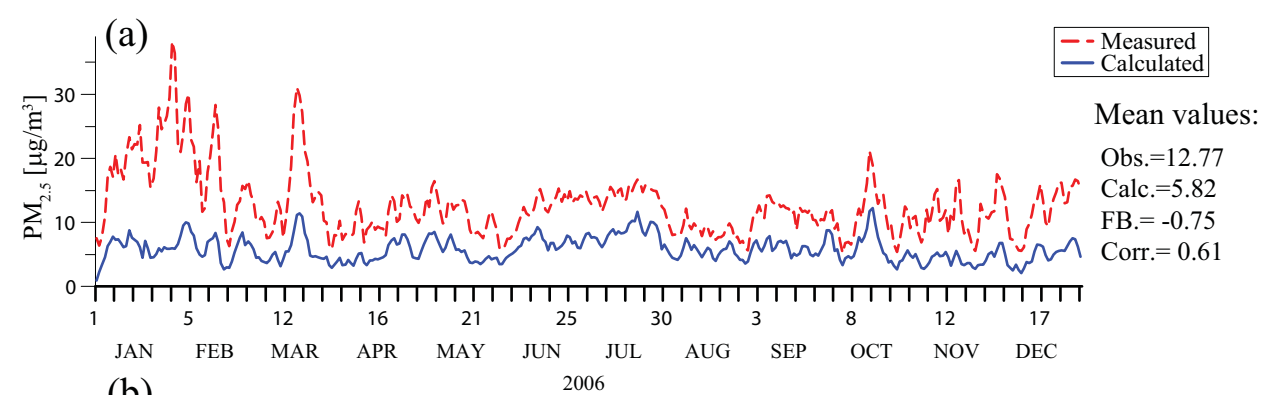

(b)

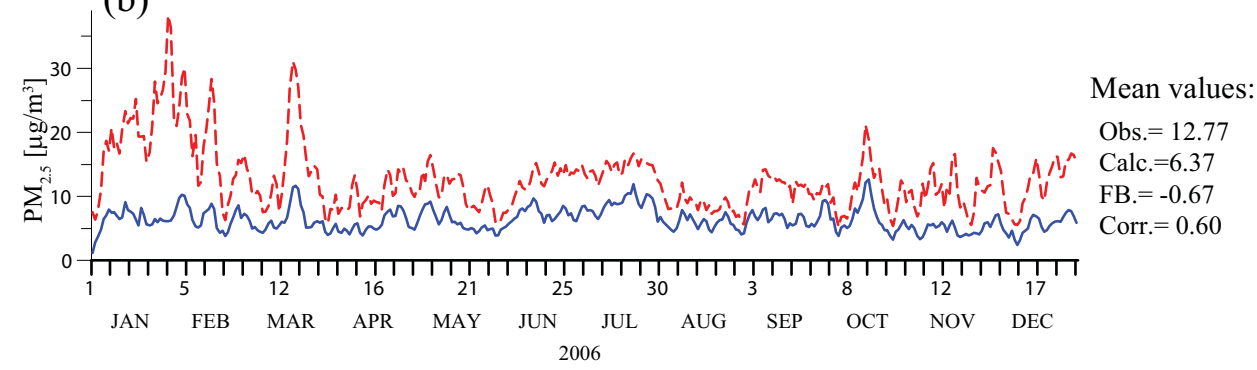

Fig. 10. Evaluation of the simulated total $\mathrm{PM}_{2.5}$ concentrations $\left(\mu \mathrm{g} \mathrm{m}^{-3}\right)$ from (a) the recent, and (b) the revised versions of DEHM against measured data from the EMEP network. The revised version includes SOA concentrations, as well as using the alternative sea-salt emissions. Total $\mathrm{PM}_{2.5}$ in DEHM includes black carbon, organic carbon (primary and secondary), sea salt and secondary inorganic aerosol.

PM underestimation. The differences between simulated and observed PM values are revealed to be more pronounced in this season.

\section{Impacts of natural emissions on air pollution levels}

To study the contribution of emissions from all the natural sources to ozone and fine PM, here, we have focused on the specific year 2006 as an example period. We have conducted a sensitivity simulation by turning off all the natural emissions (hereafter NO-NE) against a control simulation. The control simulation considers all emission sources including both anthropogenic and natural source types. Figure 11 shows the annual average ozone mixing ratio for both simulated cases (anthropogenic emissions only or all emission included) for the year 2006, together with their absolute 

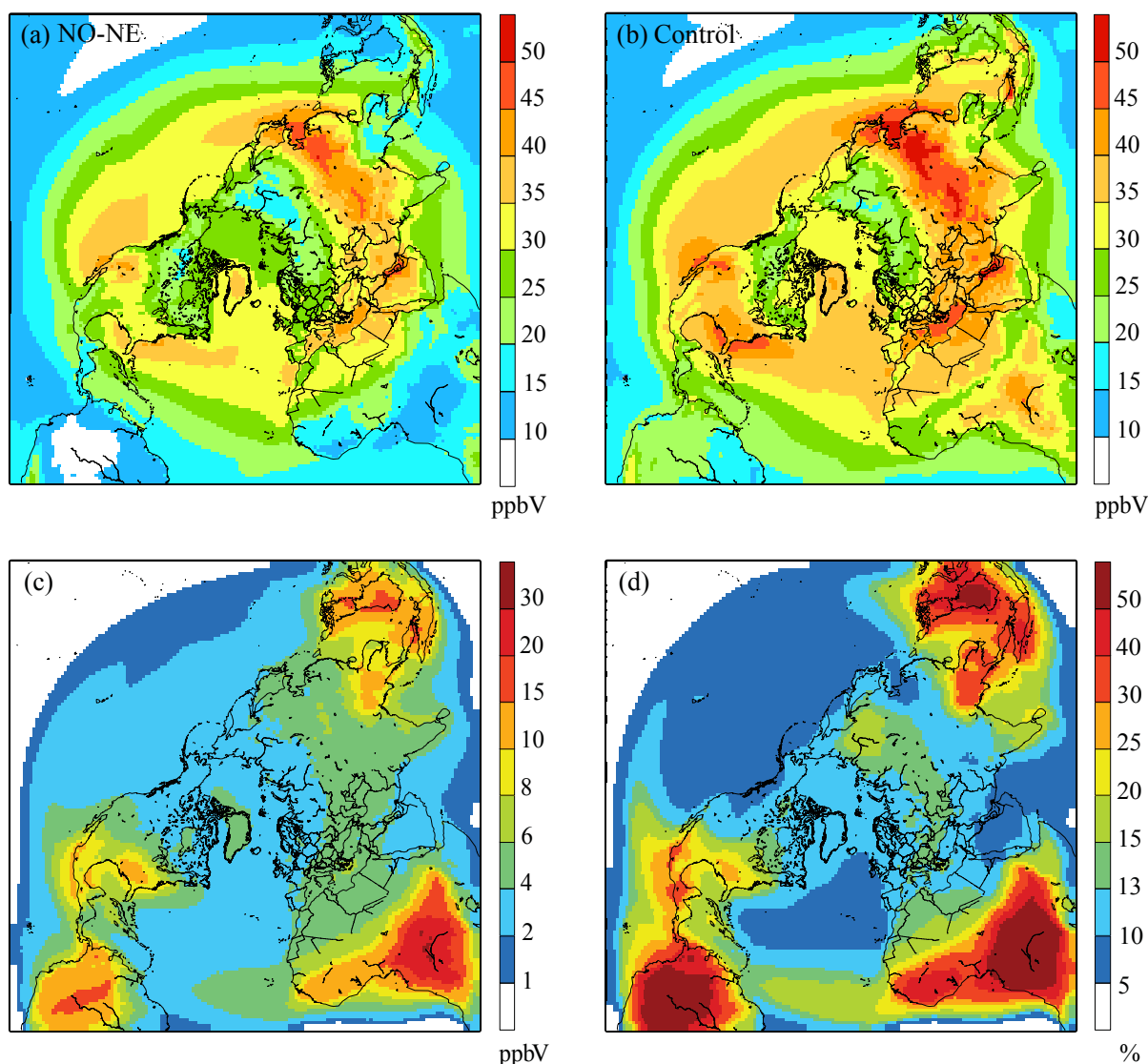

Fig. 11. The annual average ozone mixing ratios (ppbV) simulated by DEHM for (a) a sensitivity simulation by turning off all natural emissions (NO-NE), and (b) a control simulation including all emission sources, for 2006, together with (c) their absolute, (d) and relative percentage differences.

and relative differences. The highest ozone mixing ratios are depicted at mid-latitudes where high $\mathrm{NO}_{\mathrm{x}}$ emissions coincide with high VOCs. However, the highest contribution of the natural emissions to ozone mixing ratios is found to be in the tropic, with values of greater than $50 \%$. Additionally, a significant annual average increase up to $25 \%$ of ozone production due to natural emissions is observed in the southeastern US. The results can be explained by the BVOC emission distributions that show the largest isoprene emissions in the tropic and temperate regions in the southeastern US throughout the summertime (Zare et al., 2012). On the contrary, lower contributions are observed over the densely populated regions of Beijing and Shanghai in China and New Delhi in India with values between 5-10\%.

Over Europe, the ozone mixing ratios are highest in the southern and central parts, especially over the Mediterranean Sea, whereas the contribution from natural emissions enhances the ozone mixing ratios by $13-15 \%$ over the Black Sea, as well as over land areas such as Eastern Europe, Greece and Italy. The absolute contribution from natural emission lies between 4-6 ppbV in these areas while the contribution is $2-4 \mathrm{ppbV}$ in the northern and western parts of Europe. Generally, Fig. 11c shows that over the model domain, natural and biogenic emissions can enhance the ozone mixing ratio by up to $30 \mathrm{ppbV}$, particularly over land.

In the following, we investigate more specifically the contributions of each individual natural source to the ozone production. Figure 12 shows the relative differences between the ozone mixing ratios from simulations where the emissions from each natural source are excluded, and that obtained from the control simulation. In this study, natural emissions from soil, lightning, vegetation and wildfires are considered to contribute to ozone formation as a result of emitting compounds of VOCs and oxides of nitrogen $\left(\mathrm{NO}_{\mathrm{x}}\right)$.

$\mathrm{NO}$ is emitted from soil microbial processes (nitrification/denitrification) together with NO from other sources, can be oxidised quickly to $\mathrm{NO}_{2}$. Figure 12 a displays the relative contribution of $\mathrm{NO}_{\mathrm{x}}\left(=\mathrm{NO}+\mathrm{NO}_{2}\right)$ from soils $\left(\mathrm{SNO}_{\mathrm{x}}\right)$ to the tropospheric ozone mixing ratio over the model domain. The highest $\mathrm{SNO}_{\mathrm{x}}$ contributions (above $10 \%$ ) to ozone 

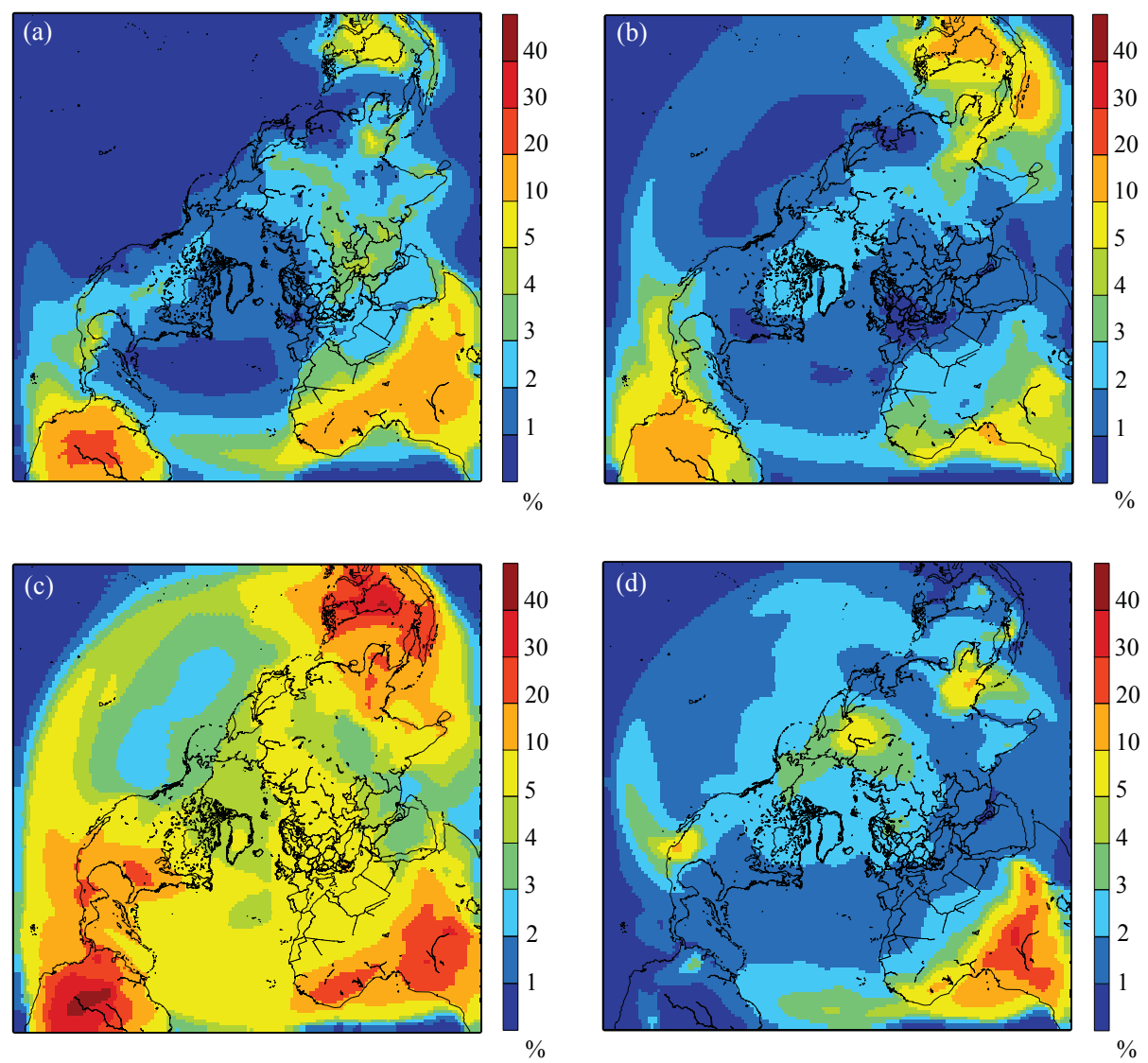

Fig. 12. Relative contributions (\%) of the natural sources with emissions of (a) $\mathrm{SNO}_{\mathrm{x}}\left(\mathrm{NO}_{\mathrm{x}}\right.$ from soils), (b) $\mathrm{LNO}_{\mathrm{x}}\left(\mathrm{NO}_{\mathrm{x}}\right.$ from lightning), (c) biogenic VOCs, and (d) wildfire emissions to annual average ozone mixing ratios in 2006.

mixing ratio are seen in the tropical regions, which can be explained by the strong dependency of soil emissions to the temperature and ecosystem type (Yienger and Levy, 1995). The largest relative contribution from $\mathrm{SNO}_{\mathrm{x}}$ occurs in the rainforest of South America, in the range of 20$30 \%$ (Fig. 12a). The contribution from lightning $\left(\mathrm{LNO}_{\mathrm{x}}\right)$ is shown in Fig. 12b, which shows that the largest contribution to ozone mixing ratios is up to $20 \%$. $\mathrm{NO}_{\mathrm{x}}$ emissions from lightning are identified mostly as a significant contributor to ozone production in the middle and upper troposphere (Stockwell et al., 1999; Zhang et al., 2003; Aghedo et al., 2007). Here, its importance with respect to ozone is investigated in the lowest model layer (thickness around $12 \mathrm{~m}$ ). The largest contribution of $\mathrm{LNO}_{\mathrm{x}}$ to ozone mixing ratio is found over South America and Southeast Asia and is in the range of $10-20 \%$. These areas are favourable for more lightning due to high temperatures and convective clouds.

The role of natural $\mathrm{NO}_{\mathrm{x}}$ emissions from lightning and soil is not essential for ozone formation in some regions such as the northeastern part of the US and Europe and is limited to only $2 \%$, as a result of high anthropogenic $\mathrm{NO}_{\mathrm{x}}$ emis- sions in these regions. On the contrary, Fig. 12c shows that the BVOC emissions can significantly contribute to ozone production everywhere over the domain. Removing BVOC emissions reduces ozone mixing ratios by $40 \%$ in the tropics, especially in South America, where the largest emissions also have been estimated by the model (Guenther et al., 2006; Zare et al., 2012). In the southeastern part of the United States, the BVOC contributions to annual mean ozone are found to be between 20 and $30 \%$ and it can be larger throughout the summertime due to temperate forests with high fluxes of isoprene.

Another natural source of VOCs (and other species) is wildfires. Contribution of the total emissions from wildfires to ozone production is presented in Fig. 12d. Although the trace gases of $\mathrm{CH}_{4}, \mathrm{NH}_{3}, \mathrm{CO}, \mathrm{NO}_{\mathrm{x}}$ and non-methane VOCs (NMVOCs) are emitted from wildfires, $\mathrm{NO}_{\mathrm{x}}$ and NMVOCs are the most important ozone precursors. Although emissions of methane and carbon monoxide are important for the increase in the background levels, they are long-lived species compared to $\mathrm{NO}_{\mathrm{x}}$ and NMVOCs. As depicted, large-scale savannah burning in the dry season in Africa can lead to an 

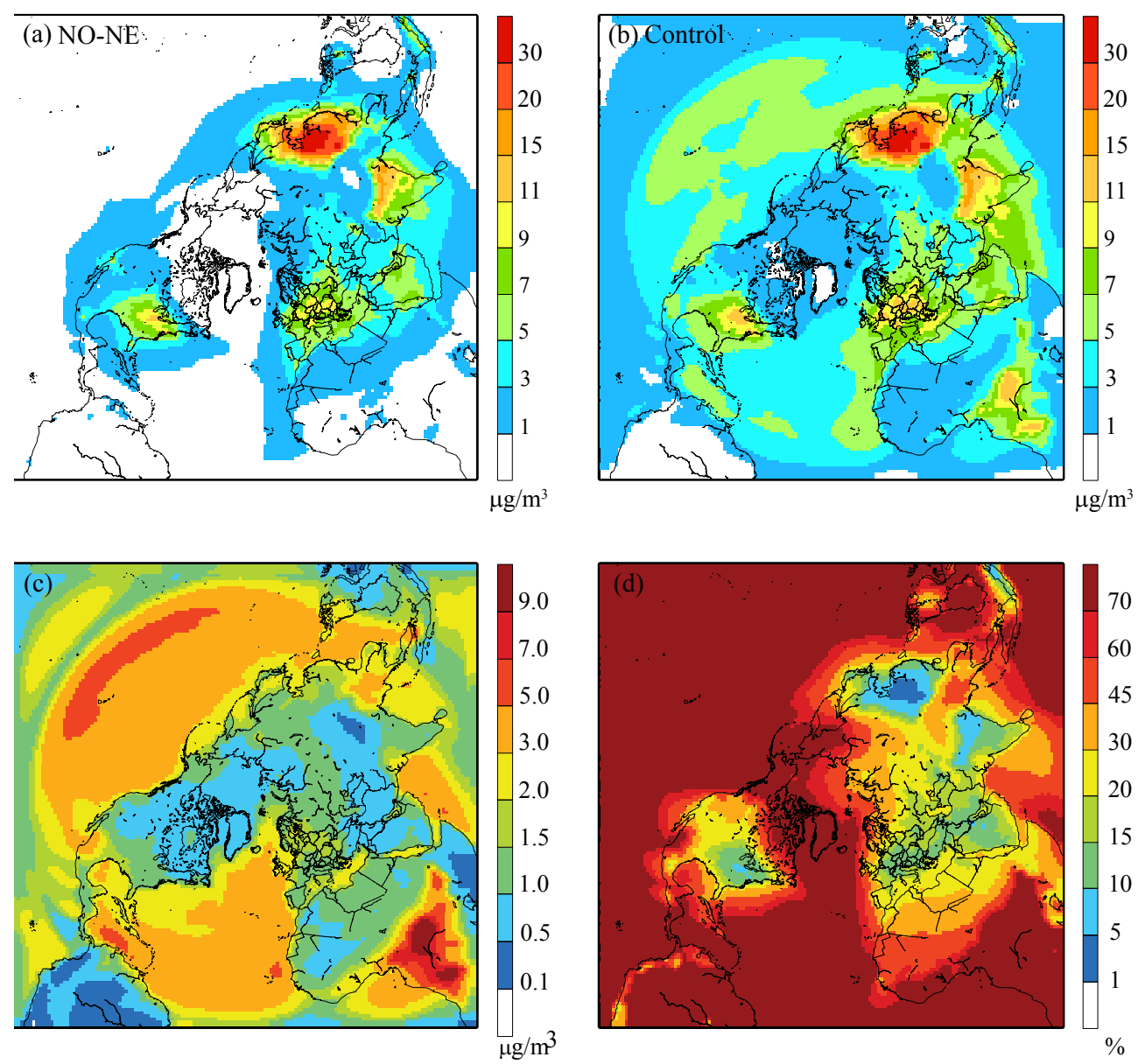

Fig. 13. The annual average $\mathrm{PM}_{2.5}$ concentrations $\left(\mu \mathrm{g} \mathrm{m}^{-3}\right)$ simulated by DEHM for (a) a sensitivity simulation by turning off all natural emissions (NO-NE), and (b) a control simulation including all emission sources, for 2006, together with (c) their absolute, (d) and relative differences.

enhanced ozone mixing ratio of above $20 \%$. Although a large number of burnings occur throughout the tropical regions, the emissions are highest in Africa due to lower humidity. On the other hand, Jaffe and Wigder (2012) stated that the nitrogen content of fuels released from savannah fires is high, that can enhance the ozone formation. Other spots with relatively high contributions from wildfires can be seen in Siberia, in the southwestern part of the US, and in the forests in Thailand with values in the range of 5-10\%.

The effects of naturally emitted primary particles, as well as natural and biogenic emissions, which can contribute to secondary aerosol formations and thereby to $\mathrm{PM}_{2.5}$ are studied in the following. The spatial distribution of total fine particles calculated by the NO-NE simulation against the control simulation is shown in Fig. 13, together with the absolute and relative differences. As expected, the aerosols produced due to human activities are dominant in the industrial and populated areas, such as the northeastern part of the US, central Europe and large parts of India (Fig. 13a), and the contribution of natural emissions to the total $\mathrm{PM}_{2.5}$ is less than
$15 \%$ (Fig. 13d). In East Asia, China, natural sources can contribute to total $\mathrm{PM}_{2.5}$ even lower by only up to $5 \%$. As it is observed in Fig. 13d, in North America, $\mathbf{P M}_{2.5}$ is dominated by anthropogenic sources across the East and by natural sources in the West with contributions by up to $70 \%$. There are similarities between the distributions of natural contributions to $\mathrm{PM}_{2.5}$ in the current study and those found by Mueller and Mallard (2011), in this region.

The high contribution from natural sources by more than $70 \%$ over oceans, seen in Fig. 13d, are owing to salt from sea spray, which contributes by up to $7 \mu \mathrm{g} \mathrm{m}^{-3}$ to the aerosol concentration. Although in the tropics, in Southeast Asia and South America, the contributions also reach to $70 \%$, the particle production due to natural sources are low in absolute terms with contribution of up to only $1 \mu \mathrm{g} \mathrm{m}^{-3}$. The investigation of specific natural sources in these regions will be done subsequently. The most striking result to emerge is that in the savannah and tropical forests in Africa, natural sources enhance the fine PM level by more than $11 \mu \mathrm{g} \mathrm{m}^{-3}$. This is 

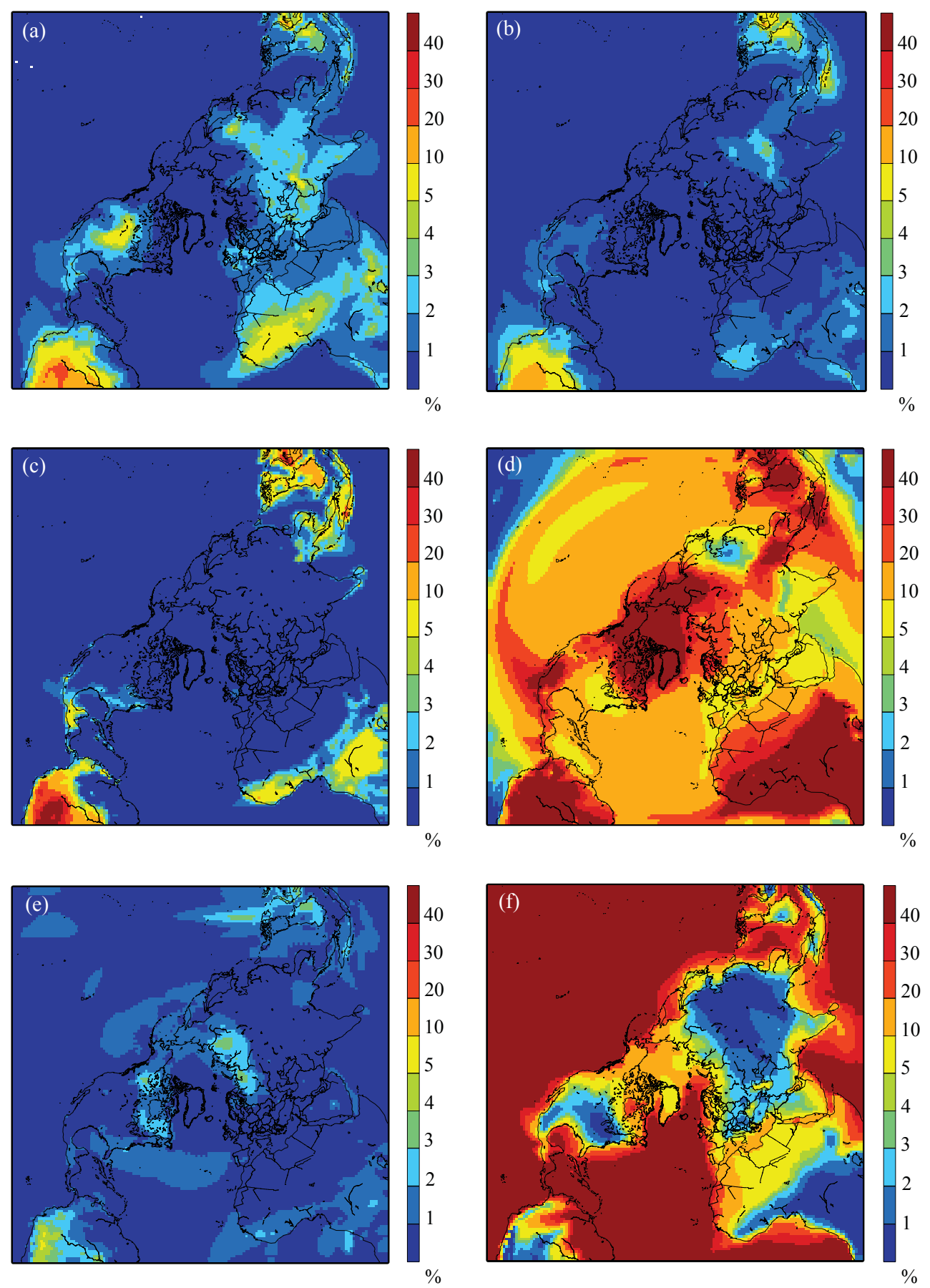

Fig. 14. Relative contributions (\%) of the natural sources to annual average $\mathrm{PM}_{2.5}$ concentrations in 2006. The impacts of natural emissions of (a) $\mathrm{SNO}_{\mathrm{x}}\left(\mathrm{NO}_{\mathrm{x}}\right.$ from soils), (b) $\mathrm{LNO}_{\mathrm{x}}\left(\mathrm{NO}_{\mathrm{x}}\right.$ from lightning), (c) biogenic VOCs, emissions (d) from wildfires, (f) natural $\mathrm{NH}_{3}$, and (e) sea salt on $\mathrm{PM}_{2.5}$ levels are shown.

comparable with anthropogenic productions in some industrial regions, e.g. in northeastern US.

The impacts on the $\mathrm{PM}_{2.5}$ levels from inclusion of $\mathrm{NO}_{\mathrm{x}}$ emissions from soil and lightning, natural $\mathrm{NH}_{3}$, VOC emissions from biogenic and sea salt, together with emissions from wildfires are shown for every single source type in
Fig. 14. Overall, wild land and agricultural fires are identified as the most important sources over land, while over oceans sea-salt emissions play the major role, as expected.

The largest increases of $\mathrm{PM}_{2.5}$ due to $\mathrm{NO}$ emissions are mostly seen over South America, where the contribution of soil is relatively higher than lightning (20-30\% against 
10-20\%). Compared to the other natural emissions, the contribution from natural ammonia to the fine PM concentration is low over the model domain (Fig. 14e). This is expected since $\mathrm{NH}_{3}$ emissions from natural sources are minor compared to other source categories (not shown). Furthermore, the maximum contribution from natural ammonia is found in the tropical savannah and adjoining wildlife parks, while the emissions of sulphur dioxide and nitrogen oxides, required for formation of SIAs, are low in the region. Another side of this issue can be seen in Fig. 14a, where the anthropogenic ammonia emissions are relatively high over North America and West Africa. Natural $\mathrm{NO}_{\mathrm{x}}$ with ammonia reacts to form ammonium nitrate aerosols, contributing to the total fine aerosols by $5-10 \%$.

As already discussed, the tropical regions and the southeastern US are favourable for a majority of the BVOC emissions, as SOA precursors, and therefore the highest contribution from BVOCs to the total $\mathrm{PM}_{2.5}$ takes place in the proximity of these sources (Fig. 14c). In spite that the production of SOAs in the tropical zone of South America, Southeast Asia and Africa are in the same order (in the range of $0.1-0.5 \mu \mathrm{g} \mathrm{m}^{-3}$ Fig. 5a), the relative contribution is highest in South America (Fig. 14c) due to the low total fine particles shown in Fig. 13b.

Wildfires can enhance the fine particles not only due to emissions of gases like $\mathrm{NO}_{\mathrm{x}}$ and $\mathrm{NH}_{3}$ to produce SIAs, and VOCs to form SOAs, but also because of primary aerosol emissions such as organic carbon and elemental carbon. The primary aerosols play the most important roles with respect to the contribution to the total $\mathrm{PM}_{2.5}$ levels. In general, the highest contributions are seen near fires and in downwind areas by more than $40 \%$. In contrast to Fig. 12d, wildfire emissions, at the higher latitudes, are also estimated to have a high contribution by more than $40 \%$ to $\mathrm{PM}_{2.5}$. The total PM concentrations are typically low in the Arctic and therefore the wildfire contribution in Siberia can be large in the Arctic. Another possible explanation for this might be that at higher latitudes, fires burn at lower temperatures, which lead to smoldering combustion to be dominant, in contrast to flaming combustion (Lapina et al., 2008). The process of smoldering tends to release larger amounts of $\mathrm{NH}_{3}$ and lower amounts of NO and (Jaff and Wider, 2012), and eventually leads to lower concentrations of ozone. Moreover, a large value of $\mathrm{NO}_{\mathrm{x}}$ emitted by boreal wildfires can rapidly convert to Peroxyacetyl nitrate (PAN) due to lower temperature (Jacob et al., 1992). PAN is an organic compound found in photochemical smog. Moreover, one can expect that the existence of $\mathrm{NH}_{3}$ besides low temperatures at high latitudes could be favourable for more SIA formation. On the other hand, ozone production requires both $\mathrm{NO}_{\mathrm{x}}$ and NMVOCs. Therefore, higher VOCs (from vegetation) in tropics can make the region more favourable to form ozone, compared to the North, during wildfire events.

The contribution from wildfires to the total atmospheric fine particles in Eastern Europe and Russia is estimated in

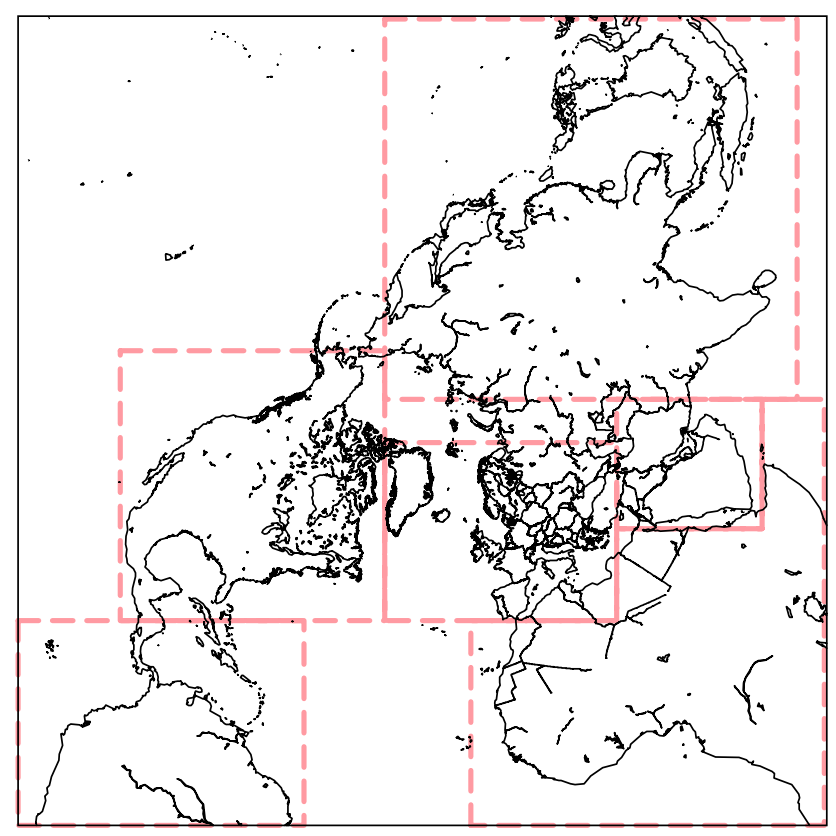

Fig. 15. The DEHM mother domain used in this study which covering more than the Northern Hemisphere, together with six regions; North America, South America, Asia, Europe, Middle East and Africa. Total contributions from individual natural source category to ozone and $\mathrm{PM}_{2.5}$ level over the six regions are calculated.

the range of $10-30 \%$. This is higher than the contribution of $5-10 \%$ in the western part of Europe. The difference is partly due to the large number of forest and grassland fires happening during summer in Eastern Europe, and crop residue burning, which is a common practice in the regions. The west to east gradients of wildfire contribution, found in the current study, is consistent with that of Barnaba et al. (2011), who estimated the relative contribution of fires to the European aerosol burden using long-term satellitebased measurements. Although we estimate the general impact of wildfires to the fine particles level to be $5-10 \%$ in the southern part of Europe, in the Mediterranean region, higher contributions of $10-20 \%$ are seen in the Iberian Peninsula. Adame et al. (2012) found that wildfire events occur in the northwestern part of the Iberian Peninsula, and pollutants could to be transported approximately $1000 \mathrm{~km}$ from north to south. Moreover, in Fig. 14d, a relatively remarkable contribution of $30-40 \%$ is seen over Northern Europe (Scandinavian countries) where major biomass burning episodes can take place (Saarikoski et al., 2007).

Figure $14 \mathrm{f}$ shows the effect of calculated sea salt on the concentration of fine particulate matter. As expected, and already mentioned, the sea salt is the most significant contributor to $\mathrm{PM}_{2.5}$ concentration over the oceans. However, the sea-salt aerosols generated, over oceans, can be driven by wind to the land. This simulation considers the fraction of fine sea-salt particles (with slower gravitational settling) and 
Table 4. Relative contributions (\%) of the natural sources with emissions of (a) $\mathrm{SNO}_{\mathrm{X}}\left(\mathrm{NO}_{\mathrm{x}}\right.$ from soils), (b) $\mathrm{LNO}_{\mathrm{x}}\left(\mathrm{NO}_{\mathrm{x}}\right.$ from lightning), (c) BVOCs, and (d) wildfire emissions to annual average ozone mixing ratios in 2006. They are calculated for the DEHM mother domain used in this study (Northern Hemisphere), together with six regions. Mean annual ozone mixing ratios (ppbV) averaged over each region (Mean) are shown for the control case with including all emission sources.

\begin{tabular}{llllllll}
\hline Regions & Mean $(\mathrm{ppbV})$ & Soil & Lightning & BVOCs & Wildfires & NO-NE & Sum \\
\hline North America & 33.4 & 1.9 & 1.9 & 9.7 & 2.5 & 15.9 & 16.0 \\
South America & 22.1 & 12.7 & 10 & 24.4 & 1.1 & 42.4 & 48.2 \\
Asia & 35.1 & 2.6 & 3.2 & 10.0 & 2.6 & 18.1 & 18.4 \\
Europe & 34.2 & 2.2 & 1.4 & 6.4 & 2.1 & 12.3 & 12.1 \\
Middle East & 38.7 & 3.0 & 1.5 & 4.3 & 1.4 & 10.1 & 10.2 \\
Africa & 32.0 & 8.5 & 3.4 & 13.6 & 8.6 & 33.6 & 34.1 \\
Northern Hemisphere & 32.6 & 4.8 & 3.2 & 11.1 & 3.9 & 22.3 & 23.0 \\
\hline
\end{tabular}

Table 5. Relative contributions (\%) of the natural sources to annual average $\mathrm{PM}_{2.5}$ concentrations in 2006. The impacts of natural emissions of $\mathrm{SNO}_{\mathrm{x}}\left(\mathrm{NO}_{\mathrm{x}}\right.$ from soils), $\mathrm{LNO}_{\mathrm{x}}\left(\mathrm{NO}_{\mathrm{x}}\right.$ from lightning), BVOCs, together with emissions from wildfires, natural $\mathrm{NH}_{3}$, and sea salt on $\mathrm{PM}_{2.5}$ level are showed. They are calculated for the DEHM mother domain used in this study (Northern Hemisphere), as well as for the six individual regions. Mean annual $\mathrm{PM}_{2.5}$ concentrations $\left(\mu \mathrm{g} \mathrm{m}^{-3}\right.$ ) averaged over each region (Mean) are shown for the control case including all emission sources.

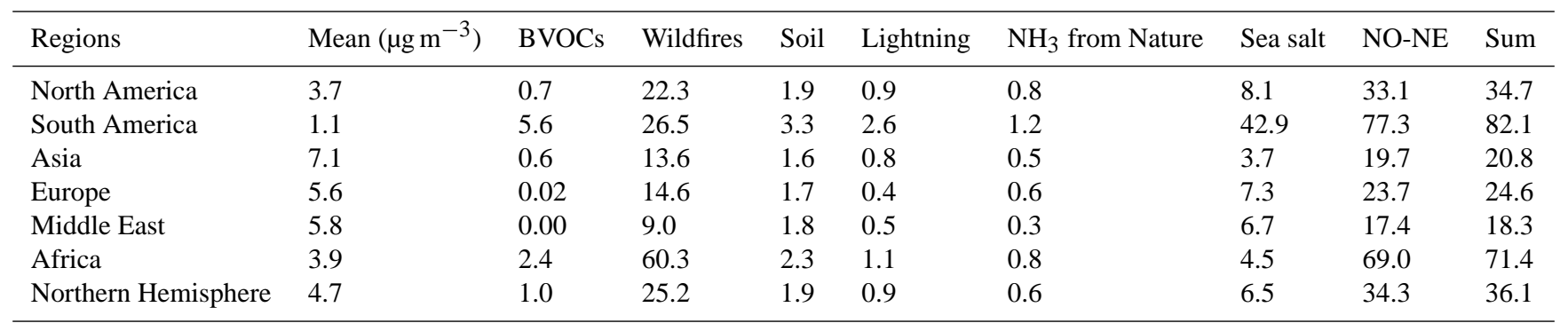

therefore the aerosols are subject to travel longer distances in the model. Apparently, the concentration of the particulate matter is enhanced at coastal area by at least $10-20 \%$ and in-land by up to $5 \%$, on average.

Tables 4 and 5 summarise the total contribution from the individual source categories to ozone and $\mathrm{PM}_{2.5}$ levels over land surfaces. The relative contributions are calculated for the domain covering the Northern Hemisphere (the DEHM mother domain) as well as for the six continental regions: North America, northern part of South America, Asia, Europe, Middle East and northern and central part of Africa. Figure 15 displays the extent of these regions in our study.

Overall, BVOCs are found to be the major contributors to the ozone increases, by $11 \%$ (on the mother domain), and emissions from wildfires enhance $\mathrm{PM}_{2.5}$ level by about $25 \%$ and are the dominant natural contributors. The overall results are similar over the individual regions, except for South America where sea-salt aerosols are estimated as the highest natural contributor to the total $\mathrm{PM}_{2.5}$ with about $43 \%$. In the rest of the regions, sea salt is the second most important contributor to fine particles over lands. No similarity among the regions for the second most important natural contributor to ozone is observed. It is seen that wildfires in North America, soil in South America and Middle East, and lightning in Asia.
We already discussed that the role of naturally emitted ammonia in forming $\mathrm{PM}_{2.5}$ is not significant (Fig. 14e). Table 5 shows that the contribution of biogenic sources of VOCs to the total value of $\mathrm{PM}_{2.5}$ in some of the regions (e.g. Europe and Middle East) is even smaller than that of ammonia.

To sum up, the effects of emissions from all natural sources combined (NO-NE simulations) are estimated to be highest in South America, followed by Africa. The relative contributions of natural sources reach to significant amounts of up to $42 \%$ for ozone and up to $77 \%$ for $\mathrm{PM}_{2.5}$. These target regions can be identified as areas with less human activities, as well as having ideal environmental conditions for natural and biogenic emissions.

The last columns in Tables 4 and 5 are included as an air pollution modelling exercise. They show that the sum of the relative contributions obtained from every single source (referred to as the Sum in the tables) can be different from the NO-NE simulation results. The contribution from all natural emissions to the total ozone mixing ratios over the model domain is found to be about $23 \%$ when we calculate it as the sum of all the individual contributions (Sum case), while it is estimated to be about $22 \%$ when turning off all the natural emissions simultaneously (NO-NE simulations). However, in specific areas the differences can be up to 6 percent. The expected differences are due to nonlinearity in the processes 
of atmospheric chemistry. The discrepancies presented in the tables shows to be different from region to region, because of different atmospheric chemical regimes in each individual region (Brandt et al., 2013a, b).

\section{Conclusion}

In this study, we have used the long-range chemical transport model, DEHM, to investigate effects of natural emissions on the concentration levels of ozone and fine particles in the troposphere. The emissions from some natural sources used in the current modelling practice were updated and evaluated. The updated model, which uses a two-product scheme for the SOA simulations, underestimates available organic aerosol observations in Europe. However, compared to the data from US monitoring sites, they show better agreements. The model results for monoterpenes alone show a good agreement with measurements, especially in Europe. The updated sea-salt functions (combination of Mårtensson et al. (2003) and Monahan et al. (1986) source functions) provide larger fine sea-salt concentrations and this shows a significant improvement of model results against available EMEP observations for 2006.

The mean contribution from all natural emissions has been investigated with respect to ozone and $\mathrm{PM}_{2.5}$ concentrations in 2006 and found to be about $22 \%$ and $34 \%$, respectively, over the model domain. In general, combination of emissions from natural sources of soil, vegetation, lightning and wildfire contribute to the ozone mixing ratios in the range of 4$30 \mathrm{ppbV}$ and together with ammonia from nature and sea salt to fine particles in the range of $0.1-11 \mu \mathrm{g} \mathrm{m}^{-3}$ over land. The highest calculated values for both ozone and PM were seen in Africa. However, the relative contributions from natural sources to ozone and PM were largest in South America with contributions of about $42 \%$ and $77 \%$, respectively.

In conclusion, the major natural contributors to ozone for the year 2006 were found to be BVOCs, over the mother domain. The dominant natural contributors to the $\mathrm{PM}_{2.5}$ levels are wildfire emissions over land and sea-salt aerosols over oceans. Moreover, simulations were conducted to specifically assess the contributions from the individual natural source categories in six continental scale regions: North America, northern part of South America, Asia, Europe, Middle East and northern and central part of Africa. The common feature observed over all regions is that the contribution from BVOCs to ozone formation is the most important amongst the natural emissions. However, considering the total fine PM over land, the wildfire emissions lead to highest enhancement over all regions except South America where sea-salt particles are the major contributor. It is noteworthy that the current study calculates the annual relative contributions from the individual natural emission categories over the land areas in each region. However, investigations in shorter periods and more limited areas can lead to different results.
To sum up, our study clearly indicates that emissions from natural and biogenic sources significantly influence the air pollution levels. In order to derive reliable conclusions, it is needed to document a relatively good agreement between the total simulated ozone and PM concentrations with measurements as well as their precursors. In this study, we have specifically focused on BVOCs, SOAs and sea salt with respect to improving and evaluating the model. However, the model, along the line of most chemistry transport models, underestimates the $\mathrm{PM}_{2.5}$ concentrations. Model evaluations for the individual compounds demonstrate that the simulated secondary inorganic aerosols and sea salt are in a good agreement with measurements. Limitations of the current model performance for fine particles in Europe can partly be related to missing windblown dust from the Sahara desert where the dust aerosols play an important role in the PM concentrations in parts of southern Europe, Africa and even the Middle East. However, the dust aerosols contribute mainly to the coarse fraction of PM, and a minor part to fine PM. On the other hand, the underestimation of SOA in Europe was about a factor of 2 (Table 3 ). We may therefore conclude that better estimations of SOA can significantly improve ability of the model to simulate fine PM levels, at least in Europe. Future work, hence, will be devoted to update DEHM with an improved scheme for secondary formed organic aerosols. However, as shown in the winter time the differences between simulated and observed PM values are also evident. That can be caused by accompanied uncertainties within emissions of black and organic carbons from anthropogenic sources and biomass burning.

The results in this paper have focused on quantifying the contribution from natural emission to air pollution levels at the Northern Hemispheric scale for a specific year, 2006. Future work will focus on the large inter-annual variability (e.g., Park et al., 2013), where significant uncertainties are associated with estimation and modelling of the short-term variability of the natural emissions. It will be interesting to expand this work to cover multi-year simulations where the climatology of the natural emissions can be studied and the development over decades can be quantified and assessed.

Acknowledgements. We express our gratitude to Karl B. Haase (University of New Hampshire), Bernard Heinesch (University of Liège), Taina Ruuskanen (University of Helsinki) and Karena McKinney (Amherst College, MA) for sharing the measurement data of monoterpenes and discussion on the results. We also thank Christopher Hoyle at Institute for Atmospheric and Climate Science, ETH Zurich, regarding his assistance in organic aerosol modelling.

Edited by: A. Pozzer 


\section{References}

Adame, J. A., Hernández-Ceballos, M. A., Bolívar, J. P., and De la Morena, B.: Assessment of an air pollution event in the southwestern Iberian Peninsula, Atmos. Environ., 55, 245-256, 2012.

Aghedo, A. M., Schultz, M. G., and Rast, S.: The influence of African air pollution on regional and global tropospheric ozone, Atmos. Chem. Phys., 7, 1193-1212, doi:10.5194/acp-7-11932007, 2007.

Allen, D. J., Pickering, K. E., Pinder, R. W., Henderson, B. H., Appel, K. W., and Prados, A.: Impact of lightning-NO on eastern United States photochemistry during the summer of 2006 as determined using the CMAQ model, Atmos. Chem. Phys., 12, 1737-1758, doi:10.5194/acp-12-1737-2012, 2012.

Atkinson, R.: Atmospheric chemistry of VOCs and $\mathrm{NO}_{\mathrm{x}}$, Atmos. Environ., 34, 2063-2101, 2000.

Barnaba, F., Angelini, F., Curci, G., and Gobbi, G. P.: An important fingerprint of wildfires on the European aerosol load, Atmos. Chem. Phys., 11, 10487-10501, doi:10.5194/acp-1110487-2011, 2011.

Bossioli, E., Tombrou, M., Karali, A., Dandou, A., Paronis, D., and Sofiev, M.: Ozone production from the interaction of wildfire and biogenic emissions: a case study in Russia during spring 2006, Atmos. Chem. Phys., 12, 7931-7953, doi:10.5194/acp-12-79312012, 2012.

Bouwman, A. F., Lee, D. S., Asman, W. A. H., Dentener, F. J., Vander Hoek, K. W., and Olivier, J. G. J.: A global high-resolution emission inventory for ammonia, Glob. Biogeochem. Cy., 11, 561-587, 1997.

Brandt, J., Silver, J., Frohn, L., Geels, C., Gross, A., Hansen, A., Hansen, K., Hedegaard, G., Skjøth, C., Villadsen, H., Zare, A., and Christensen, J. H.: An integrated model study for Europe and North America using the Danish Eulerian Hemispheric Model with focus on intercontinental transport of air pollution, Atmos. Environ., 53, 156-176, 2012.

Brandt, J., Silver, J. D., Christensen, J. H., Andersen, M. S., Bønløkke, J. H., Sigsgaard, T., Geels, C., Gross A., Hansen, A. B., Hansen, K. M., Hedegaard, G. B., Kaas, E., and Frohn, L. M.: Contribution from the ten major emission sectors in Europe and Denmark to the health-cost externalities of air pollution using the EVA model system - an integrated modelling approach, Atmos. Chem. Phys., 13, 7725-7746, doi:10.5194/acp-13-77252013, 2013a.

Brandt, J., Silverv, J. D., Christensen, J. H., Andersen, M. S., Bønløkke, J. H., Sigsgaard, T., Geels, C., Gross A., Hansen, A. B., Hansen, K. M., Hedegaard, G. B., Kaas, E., and Frohn, L. M.: Assessment of Past, Present and Future Health-Cost Externalities of Air Pollution in Europe and the contribution from international ship traffic using the EVA Model System, Atmos. Chem. Phys., 13, 7747-7764, doi:10.5194/acp-13-7747-2013b.

Christensen, J. H.: The Danish Eulerian Hemispheric Model - a three-dimensional air pollution model used for the Arctic, Atmos. Environ., 31, 4169-4191, 1997.

Chung, S. H. and Seinfeld, J. H.: Global distribution and climate forcing of carbonaceous aerosols, J. Geophys. Res., 107, 4407, doi:10.1029/2001JD001397, 2002.

Curci, G., Beekmann, M., Vautard, R., Smiatek, G., Steinbrecher, R., Theloke, J., and Friedrich, R.: Modelling study of the impact of isoprene and terpene biogenic emissions on European ozone levels, Atmos. Environ., 43, 1444-1455, 2009.
Dasgupta, P. K., Campbell, S. W., Al-Horr, R. S., Ullah, S. M. R., Li, J., Amalfitano, C., and Poor, N. D.: Conversion of sea salt aerosol to $\mathrm{NaNO} 3$ and the production of $\mathrm{HCl}$ : Analysis of temporal behavior of aerosol chloride/nitrate and gaseous $\mathrm{HCl} / \mathrm{HNO} 3$ concentrations with AIM, Atmos. Environ., 41, 4242-4257, 2007.

de Leeuw, G., Neele, F. P., Hill, M., Smith, M. H., and Vignati, E.: Production of sea spray aerosol in the surf zone, J. Geophys. Res., 105, 29397-29409, 2000.

Delon, C., Reeves, C. E., Stewart, D. J., Serc,a, D., Dupont, R., Mari, C., Chaboureau, J. P., and Tulet, P.: Biogenic nitrogen oxide emissions from soils - impact on $\mathrm{NO}_{\mathrm{x}}$ and ozone over West Africa during AMMA (African Monsoon Multidisciplinary Experiment): modelling study, Atmos. Chem. Phys., 8, 2351-2363, doi:10.5194/acp-8-2351-2008, 2008.

Donahue, N. M., Robinson, A. L., Stanier, C. O., and Pandis, S. N.: Coupled partitioning, dilution, and chemical aging of semivolatile organics, Environ. Sci. Technol., 40, 2635-2643, 2006.

Emanuelsson, E. U., Hallquist, M., Kristensen, K., Glasius, M., Bohn, B., Fuchs, H., Kammer, B., Kiendler-Scharr, A., Nehr, S., Rubach, F., Tillmann, R., Wahner, A., Wu, H. C., and Mentel, Th. F.: Formation of anthropogenic secondary organic aerosol (SOA) and its influence on biogenic SOA properties, Atmos. Chem. Phys., 13, 2837-2855, doi:10.5194/acp-13-2837-2013, 2013.

Frohn, L. M., Christensen, J. H., and Brandt, J.: Development of a high resolution nested air pollution model - the numerical approach, J. Comput. Phys., 179, 68-94, 2002.

Gong, S. L., Barrie, L. A., and Blanchet, J. P.: Modeling sea-salt aerosols in the atmosphere: 1, Model development, J. Geophys. Res., 102, 3805-3818, 1997.

Grell, G. A., Dudhia, J., and Stauffer, D. R.: A description of the fifth-generation Penn State/NCAR mesoscale model (MM5), NCAR/TN-398 STR, Penn State/NCAR, 1994.

Griffin, R. J., Cocker, D. R., Seinfeld, J. H., and Dabdub, D.: Estimate of global atmospheric organic aerosol from oxidation of biogenic hydrocarbons, Geophys. Res. Lett., 26, 2721-2724, doi:10.1029/1999GL900476, 1999.

Guenther, A., Hewitt, N., Erickson, D., Fall, R., Geron, C., Graedel, T., Harley, P., Klinger, L., Lerdau, M., McKay, W., Pierce, T., Scholes, B., Steinbrecher, R., Tallamraju, R., Taylor, J., and Zimmerman, P.: A global model of natural volatile organic compound emissions, J. Geophys. Res., 100, 8873-8892, 1995.

Guenther, A., Karl, T., Harley, P., Wiedinmyer, C., Palmer, P. I., and Geron, C.: Estimates of global terrestrial isoprene emissions using MEGAN (Model of Emissions of Gases and Aerosols from Nature), Atmos. Chem. Phys., 6, 3181-3210, doi:10.5194/acp-63181-2006, 2006.

Guenther, A. B., Jiang, X., Heald, C. L., Sakulyanontvittaya, T., Duhl, T., Emmons, L. K., and Wang, X.: The Model of Emissions of Gases and Aerosols from Nature version 2.1 (MEGAN2.1): an extended and updated framework for modeling biogenic emissions, Geosci. Model Dev., 5, 1471-1492, doi:10.5194/gmd-51471-2012, 2012.

Haase, K. B., Jordan, C., Mentis, E., Cottrell, L., Mayne, H. R., Talbot, R., and Sive, B. C.: Changes in monoterpene mixing ratios during summer storms in rural New Hampshire (USA), Atmos. Chem. Phys., 11, 11465-11476, doi:10.5194/acp-1111465-2011, 2011. 
Hall IV, W. A. and Johnston, M. V.: Oligomer content of alphapinene secondary organic aerosol, Aerosol Sci. Technol., 45, 3745, doi:10.1080/02786826.2010.517580, 2011.

Heald, C. L., Henze, D. K., Horowitz, L. W., Feddema, J., Lamarque, J. F., Guenther, A., Hess, P. G., Vitt, F., Seinfeld, J. H., Goldstein, A. H., and Fung, I.: Predicted change in global secondary organic aerosol concentrations in response to future climate, emissions, and land use change, J. Geophys. Res.-Atmos., 113, D05211, doi:10.1029/2007jd009092, 2008.

Hedegaard, G. B., Brandt, J., Christensen, J. H., Frohn, L. M., Geels, C., Hansen, K. M., and Stendel, M.: Impacts of climate change on air pollution levels in the Northern Hemisphere with special focus on Europe and the Arctic, Atmos. Chem. Phys., 8, 3337-3367, doi:10.5194/acp-7-1193-2007, 2008.

Hedegaard, G., Christensen, J. H., Geels, C., Gross, A., Hansen, K. M., May, W., Zare, A., and Brandt, J.: Effects of Changed Climate Conditions on Tropospheric Ozone over Three Centuries, Atmos. Climate Sci., 2, 546-561, 2012.

Hedegaard, G. B., Christensen, J. H., and Brandt, J.: The relative importance of impacts from climate change vs. emissions change on air pollution levels in the 21 st century, Atmos. Chem. Phys., 13, 3569-3585, doi:10.5194/acp-13-3569-2013, 2013.

Henze, D. K. and Seinfeld, J. H.: Global secondary organic aerosol from isoprene oxidation, Geophys. Res. Lett., 33, L09812, doi:10.1029/2006GL025976, 2006.

Hodzic, A., Jimenez, J. L., Madronich, S., Canagaratna, M. R., DeCarlo, P. F., Kleinman, L., and Fast, J.: Modeling organic aerosols in a megacity: potential contribution of semi-volatile and intermediate volatility primary organic compounds to secondary organic aerosol formation, Atmos. Chem. Phys., 10, 5491-5514, doi:10.5194/acp-10-5491-2010, 2010.

Hoyle, C. R., Berntsen, T., Myhre, G., and Isaksen, I. S. A.: Secondary organic aerosol in the global aerosol chemical transport model Oslo CTM2, Atmos. Chem. Phys., 7, 5675-5694, doi:10.5194/acp-7-5675-2007, 2007.

Hoyle, C. R., Myhre, G., Berntsen, T. K., and Isaksen, I. S. A.: Anthropogenic influence on SOA and the resulting radiative forcing, Atmos. Chem. Phys., 9, 2715-2728, doi:10.5194/acp-9-27152009, 2009.

Jacob, D. J., Wofsy, S. C., Bakwin, P. S., Fan, S. M., Harriss, R. C., Talbot, R. W., Bradshaw, J. D., Sandholm, S. T., Singh, H. B., Browell, E. V., Gregory, G. L., Sachse, G. W., Shipham, M. C., Blake, D. R., and Fitzjarrald, D. R.: Summertime photochemistry of troposphere at high northern latitudes. J. Geophys. Res., 97, 16421-16431, 1992.

Jaffe, D. A. and Wigder, N. L.: Ozone production from wildfires: A critical review, Atmos. Environ., 51, 1-10, doi:10.1016/j.atmosenv.2011.11.063, 2012.

Jiang, X., Yang, Z. L., Liao, H., and Wiedinmyer, C.: Sensitivity of biogenic secondary organic aerosols to future climate change at regional scales: An online coupled simulation, Atmos. Environ, 44, 4891-4907, 2010.

Kanakidou, M., Seinfeld, J. H., Pandis, S. N., Barnes, I., Dentener, F. J., Facchini, M. C., Van Dingenen, R., Ervens, B., Nenes, A., Nielsen, C. J., Swietlicki, E., Putaud, J. P., Balkanski, Y., Fuzzi, S., Horth, J., Moortgat, G. K., Winterhalter, R., Myhre, C. E. L., Tsigaridis, K., Vignati, E., Stephanou, E. G., and Wilson, J.: Organic aerosol and global climate modeling: a review. At- mos. Chem. Phys., 5, 1053-1123, doi:10.5194/acp-5-1053-2005, 2005.

Kaynak, B., Hu, Y., Martin, R. V., Russell, A. G., Choi, Y., and Wang, Y.: The effect of lightning $\mathrm{NO}_{\mathrm{x}}$ production on surface ozone in the continental United States. Atmos. Chem. Phys., 8, 5151-5159, doi:10.5194/acp-8-5151-2008, 2008.

Koo, B., Chien, C., Tonnesen, G., Morris, R., Johnson, J., Sakulyanontvittaya, T., Piyachaturawat, P., and Yarwood, G.: Natural emissions for regional modeling of background ozone and particulate matter and impacts on emissions control strategies, Atmos. Environ., 44, 2372-2382, 2010.

Kristensen, K., Enggrob, K. L., King, S. M., Worton, D. R., Platt, S. M., Mortensen, R., Rosenoern, T., Surratt, J. D., Bilde, M., Goldstein, A. H., and Glasius, M.: Formation and occurrence of dimer esters of pinene oxidation products in atmospheric aerosols, Atmos. Chem. Phys., 13, 3763-3776, doi:10.5194/acp-13-37632013, 2013.

Laffineur, Q., Aubinet, M., Schoon, N., Amelynck, C., Muller, J. F., Dewulf, J., Van Langenhove, H., Steppe, K., Simpraga, M., and Heinesch, B.: Isoprene and monoterpene emissions from a mixed temperate forest, Atmos. Environ., 45, 3157-3168, 2011.

Lamarque, J. F., Bond, T. C., Eyring, V., Granier, C., Heil, A., Klimont, Z., Lee, D., Liousse, C., Mieville, A., Owen, B., Schultz, M. G., Shindell, D., Smith, S. J., Stehfest, E., Van Aardenne, J., Cooper, O. R., Kainuma, M., Mahowald, N., McConnell, J. R., Naik, V., Riahi, K., and Van Vuuren, D. P.: Historical (1850-2000) gridded anthropogenic and biomass burning emissions of reactive gases and aerosols: methodology and application, Atmos. Chem. Phys., 10, 7017-7039, doi:10.5194/acp10-7017-2010, 2010.

Laothawornkitkul, J., Taylor, J. E., Paul, N. D., and Hewitt, C. N.: Biogenic volatile organic compounds in the earth system, New Phytol., 183, 27-51, 2009.

Lapina, K., Honrath, R. E., Owen, R. C., Martin, M. V., Hyer, E. J., and Fialho, P.: Late summer changes in burning conditions in the boreal regions and their implications for NOx and CO emissions from boreal fires. J. Geophys. Res. Atmos., 113, D11304, doi:10.1029/2007JD009421, 2008.

Mårtensson, E. M., Nilsson, E. D., de Leeuw, G., Cohen, L. H., and Hansson, H. C.: Laboratory simulations and parameterisation of the primary marine aerosol production, J. Geophys. Res., 108, p. 4297, doi:10.1029/2002JD002263, 2003.

Makar, P. A., Moran, M. D., Zheng, Q., Cousineau, S., Sassi, M., Duhamel, A., Besner, M., Davignon, D., Crevier, L. P., and Bouchet, V. S.: Modelling the impacts of ammonia emissions reductions on North American air quality, Atmos. Chem. Phys., 9, 7183-7212, doi:10.5194/acp-9-7183-2009, 2009.

Mareckova, K., Wankmueller, R., Anderl, M., Muik, B., Poupa, S., and Wieser, M.: Inventory Review 2008: Emission Data Reported under the LRTAP Convention and NEC Directive. Status of Gridded Data. Technical report. EMEP Centre on Emission Inventories and Projections. URL, 2008.

McKinney, K. A., Lee, B. H., Vasta, A., Pho, T. V., and Munger, J. W.: Emissions of isoprenoids and oxygenated biogenic volatile organic compounds from a New England mixed forest, Atmos. Chem. Phys., 11, 4807-4831, doi:10.5194/acp-11-4807-2011, 2011.

Monahan, E. G., Spiel, D. E., and Davidson, K. L.: A model of marine aerosol generation via whitecaps and wave disruption, in 
Oceanic Whitecaps, edited by: Monahan, E. and Niocaill, G. M., 167-174, D. Reidel, Norwell, Mass., 1986.

Mueller, S. and Mallard, J.: Contributions of natural emissions to ozone and $\mathrm{PM}_{2.5}$ as simulated by the community multiscale air quality (CMAQ) model. Environ. Sci. Technol. 45, 4817-4823, 2011.

Muller, L., Reinnig, M. C., Naumann, K. H., Saathoff, H., Mentel, T. F., Donahue, N. M., and Hoffmann, T.: Formation of 3-methyl1,2,3-butanetricarboxylic acid via gas phase oxidation of pinonic acid - a mass spectrometric study of SOA aging, Atmos. Chem. Phys., 12, 1483-1496, doi:10.5194/acp-12-1483-2012, 2012.

Olivier, J. G. J., Bouwman, A. F., van der Maas, C. W. M., Berdowski, J. J. M., Veldt, C., Bloos, J. P. J., Visschedijk, A. J. H., Zandveld, P. Y. J., and Haverlag, J. L.: Description of EDGAR Version 2.0: A set of global emission inventories of greenhouse gases and ozone-depleting substances for all anthropogenic and most natural sources on a per country basis and on $1^{\circ} \times 1^{\circ}$ grid, http://www.pbl.nl/en/publications/1996/ Description_of_EDGAR_Version_2_0, Bilthoven, RIVM report no. 771060 002, 1996.

Pankow, J. F.: An absorption model of the gas/aerosol partitioning involved in the formation of secondary organic aerosol, Atmos. Environ., 28, 189-193, 1994.

Park, K., Emmons, L. K., Wang, Z., and Mak, J. E.: Large interannual variations in nonmethane volatile organic compound emissions based on measurements of carbon monoxide, Geophys. Res. Lett, 40, 221-226, 2013.

Price, C., Penner, J., and Prather, M.: $\mathrm{NO}_{\mathrm{x}}$ from lightning. 1. Global distribution based on lightning physics, J. Geophys. Res.-Atmos., 102, 5929-5941, 1997.

Pryor, S. C., Barthelmie, R, J., Schoof, J. T., Binkowski, F. S., Delle Monache, L., and Stull, R.: Modeling the impact of sea-spray on particle concentrations in a coastal city, Sci. Total Environ., 391, 132-142, 2007.

Robinson, A. L., Donahue, N. M., Shrivastava, M. K., Weitkamp, E. A., Sage, A. M., Grieshop, A. P., Lane, T. E., Pierce, J. R., and Pandis, S. N.: Rethinking organic aerosols: Semivolatile emissions and photochemical aging, Science, 315, 1259-1262, 2007.

Saarikoski, S., Sillanpaa, M., Sofiev, M., Timonen, H., Saarnio, K., Teinila, K., Karppinen, A., Kukkonen, J., and Hillamo, R.: Chemical composition of aerosols during a major biomass burning episode over northern Europe in spring 2006: Experimental and modelling assessments, Atmos. Environ., 41, 3577-3589, 2007.

Sakulyanontvittaya, T., Duhl, T., Wiedinmyer, C., Helmig, D., Matsunaga, S., Potosnak, M., Milford, J., and Guenther, A.: Monoterpene and sesquiterpene emission estimates for the United States, Environ Sci Technol., 42, 1623-1629, 2008.

Sartelet, K. N., Couvidat, F., Seigneur, C., and Roustan, Y.: Impact of biogenic emissions on air quality over Europe and North America, Atmos. Environ., 53, 131-141, 2012.

Schultz, M., Backman, L., Balkanski, Y., Bjoerndalsaeter, S., Brand, R., Burrows, J., Dalsoeren, S., de Vasconcelos, M., Grodtmann, B., Hauglustaine, D., Heil, A., Hoelzemann, J., Isaksen, I., Kaurola, J., Knorr, W., Ladstaetter-Weienmayer, A., Mota, B., Oom, D., Pacyna, J., Panasiuk, D., Pereira, J., Pulles, T., Pyle, J., Rast, S., Richter, A., Savage, N., Schnadt, C., Schulz, M., Spessa, A., Staehelin, J., Sundet, J., Szopa, S., Thonicke, K., van het Bolscher, M., van Noije, T., van Velthoven, P., Vik, A., and Wit- trock, F.: REanalysis of the TROpospheric chemical composition over the past 40 years (RETRO). A long-term global modeling study of tropospheric chemistry, Final Report, Tech. rep., Max Planck Institute for Meteorology, Hamburg, Germany, 2007.

Schultz, M. G., Heil, A., Hoelzemann, J. J., Spessa, A., Thonicke, K., Goldammer, J. G., Held, A. C., Pereira, J. M. C., and van het Bolscher, M.: Global wildland fire emissions from 1960 to 2000, Global Biogeochem. Cy., 22, GB2002, doi:10.1029/2007GB003031, 2008.

Schumann, U. and Huntrieser, H.: The global lightning-induced nitrogen oxides source, Atmos. Chem. Phys., 7, 3823-3907, doi:10.5194/acp-7-3823-2007, 2007.

Seinfeld, J. H. and Pandis, S. N.: Atmospheric Chemistry and Physics: From Air Pollution to Climate Change, 2nd edition, J. Wiley, New York, 1232 pp., 2006.

Simpson, D., Winiwarter, W., Borjesson, G., Cinderby, S., Ferreiro, A., Guenther, A., Hewitt, C. N., Janson, R., Khalil, M. A. K., Owen, S., Pierce, T. E., Puxbaum, H., Shearer, M., Skiba, U., Steinbrecher, R., Tarrason, L., and Oquist, M. G.: Inventorying emissions from nature in Europe, J. Geophys. Res., 104, 81138152, 1999.

Solazzo, E., Bianconi, R., Vautard, R., Wyat Appel, K., Moran, M. D., Hogrefe, C., Bessagnet, B., Brandt, J., Christensen, J. H., Chemel, C., Coll, I., Denier van der Gon, H., Ferreira, J., Forkel, R., Francis, X. V., Grell, G., Grossi, P., Hansen, A. B., Jericevi, A., Kraljevi, L., Miranda, A. I., Nopmongcol, U., Pirovano, G., Prank, M., Riccio, A., Sartelet, K. N., Schaap, M., Silver, J. D., Sokhi, R. S., Vira, J., Werhahn, J., Wolkem, R., Yarwood, G., Zhang, J., Trivikrama Rao, S., and Galmarini, S.: Model evaluation and ensemble modelling of surface-level ozone in Europe and North America in the context of AQMEII, Atmos. Environ., 53, 60-74, 2012a.

Solazzo, E., Bianconi, R., Pirovano, G., Matthias, V., Vautard, R., Moran, M. D., Appel, K. W., Bessagnet, B., Brandt, J., Christensen, J. H., Chemel, C., Coll, I., Ferreira, J., Forkel, R., Vazhappilly Francis, X., Grell, G., Grossi, P., Hansen, A. B., Miranda, A. I., Nopmongcol, U., Prank, M., Sartelet, K. N., Schaap, M., Silver, J. D., Sokhi, R. S., Vira, J., Werhahn, J., Wolke, R., Yarwood, G., Zhang, J., Rao, S. T., and Galmarini, S.: Operational model evaluation for particulate matter in Europe and North America in the context of AQMEII, Atmos. Environ., 53, 75-92, $2012 b$.

Solazzo, E., Bianconi, R., Pirovano, G., Moran, M. D., Vautard, R., Hogrefe, C., Appel, K. W., Matthias, V., Grossi, P., Bessagnet, B., Brandt, J., Chemel, C., Christensen, J. H., Forkel, R., Francis, X. V., Hansen, A. B., McKeen, S., Nopmongcol, U., Prank, M., Sartelet, K. N., Segers, A., Silver, J. D., Yarwood, G., Werhahn, J., Zhang, J., Rao, S. T., and Galmarini, S.: Evaluating the capability of regional-scale air quality models to capture the vertical distribution of pollutants. Geosci. Model Dev., 6, 791-818, doi:10.5194/gmd-6-791-2013, 2013.

Spracklen, D. V., Jimenez, J. L., Carslaw, K. S., Worsnop, D. R., Evans, M. J., Mann, G. W., Zhang, Q., Canagaratna, M. R., Allan, J., Coe, H., McFiggans, G., Rap, A., and Forster, P.: Aerosol mass spectrometer constraint on the global secondary organic aerosol budget, Atmos. Chem. Phys., 11, 12109-12136, doi:10.5194/acp-11-12109-2011, 2011.

Steinkamp, J., Ganzeveld, L. N., Wilcke, W., and Lawrence, M. G.: Influence of modelled soil biogenic NO emissions on related trace gases and the atmospheric oxidizing efficiency, At- 
mos. Chem. Phys., 9, 2663-2677, doi:10.5194/acp-7-1193-2009, 2009.

Stockwell, D. Z., Giannakopoulos, C., Plantevin, P. H., Carver, G. D., Chipperfield, M. P., Law, K. S., Pyle, J. A., Shallcross, D. E., and Wang, K. Y.: Modelling $\mathrm{NO}_{\mathrm{x}}$ from lightning and its impact on global chemical fields, Atmos. Environ., 33, 4477-4493, 1999.

Streets, D. G., Yan, F., Chin, M., Diehl, T., Mahowald, N., Schultz, M., Wild, M., Wu, Y., and Yu, C.: Anthropogenic and natural contributions to regional trends in aerosol optical depth, 1980-2006, J. Geophys. Res. Atmos., 114, D00D18, doi:10.1029/2008JD011624, 2009.

Taipale, R., Ruuskanen, T. M., Rinne, J., Kajos, M. K., Hakola, H., Pohja, T., and Kulmala, M.: Technical Note: Quantitative long-term measurements of VOC concentrations by PTR-MS measurement, calibration, and volume mixing ratio calculation methods, Atmos. Chem. Phys., 8, 6681-6698, doi:10.5194/acp8-6681-2008, 2008.

Tsigaridis, K. and Kanakidou, M.: Global modelling of secondary organic aerosol in the troposphere: a sensitivity analysis, Atmos. Chem. Phys., 3, 1849-1869, doi:10.5194/acp-3-1849-2003, 2003.

van der Werf, G. R., Randerson, J. T., Giglio, L., Collatz, G. J., Kasibhatla, P. S., and Arellano Jr., A. F.: Interannual variability in global biomass burning emissions from 1997 to 2004, Atmos. Chem. Phys., 6, 3423-3441, doi:10.5194/acp-6-3423-2006, 2006.

van der Werf, G. R., Randerson, J. T., Giglio, L., Collatz, G. J., Mu, M., Kasibhatla, P. S., Morton, D. C., DeFries, R. S., Jin, Y., and van Leeuwen, T. T.: Global fire emissions and the contribution of deforestation, savanna, forest, agricultural, and peat fires (19972009), Atmos. Chem. Phys., 10, 11707-11735, doi:10.5194/acp10-11707-2010, 2010.

Venevsky, S., Thonicke, K. S., Sitch, S., and Cramer, W.: Simulating fire regimes in human-dominated ecosystems: Iberian Peninsula case study, Global Change Biol., 8, 984-998, 2002.
Vestreng, V., Adams, M., and Goodwin, J.: Inventory Review 2004. Emission data reported to CLRTAP and under the NEC directive. EMEP/ EEA Joint Review Report, Tech. Rep. EMEP-MSCW Rep. 1/2004, Norw. Meteorol. Inst., Oslo, Norway, 2004.

Weijers, E. P., Schaap, M., Nguyen, L., Matthijsen, J., Denier van der Gon, H. A. C., Ten Brink, H. M., and Hoogerbrugge, R.: Anthropogenic and natural constituents in particulate matter in the Netherlands, Atmos. Chem. Phys. 11, 2281-2294, doi:10.5194/acp-11-2281-2011, 2011.

Wiacek, A., Peter, T., and Lohmann, U.: The potential influence of Asian and African mineral dust on ice, mixed-phase and liquid water clouds, Atmos. Chem. Phys., 10, 8649-8667, doi:10.5194/acp-10-8649-2010, 2010.

Williams, J. E., van Velthoven, P. F. J., and Brenninkmeijer, C. A. M.: Quantifying the uncertainty in simulating global tropospheric composition due to the variability in global emission estimates of Biogenic Volatile Organic Compounds, Atmos. Chem. Phys., 13, 2857-2891, doi:10.5194/acp-13-2857-2013, 2013.

Wu, S. Y., Hu, J. L., Zhang, Y., and Aneja, V. P.: Modeling atmospheric transport and fate of ammonia in North Carolina - Part II: Effect of ammonia emissions on fine particulate matter formation, Atmos. Environ., 42, 3437-3451, 2008.

Yienger, J. J. and Levy, H.: Empirical model of global soil-biogenic $\mathrm{NO}_{\mathrm{x}}$ emissions, J. Geophys. Res., 100, 11447-11464, 1995.

Zare, A., Christensen, J. H., Irannejad, P., and Brandt, J.: Evaluation of two isoprene emission models for use in a longrange air pollution model, Atmos. Chem. Phys., 12, 7399-7412, doi:10.5194/acp-12-7399-2012, 2012.

Zhang, R., Tie, X., and Bond, D. W.: Impacts of anthropogenic and natural NOx sources over the US on tropospheric chemistry, PNAS, 100, 1505-1509, 2003. 